\title{
27. MINERALOGY AND CHEMISTRY OF CARIBBEAN SEDIMENTS
}

\author{
Thomas W. Donnelly and Gino Nalli, Department of Geology, State University \\ of New York, Binghamton, New York
}

\section{INTRODUCTION}

The sediments of Leg 15 included several noteworthy occurrences of authigenic, volcanic (discussed elsewhere in this volume), and continentally derived minerals. Of these, the occurrence of native copper in pelagic clays, the relatively well developed crystals of clinoptilolite in several older volcanic clays, the widespread authigenic K-feldspar, and the occurrences of garnet (one of which appears to be authigenic; the other, not positively identified, may be volcanic) are especially interesting. Turbiditic mineral assemblages of continental origin found in the Venezuelan Basin only in the Miocene and Pliocene can be shown to be derived from northern Venezuela. Although the mineralogical observations discussed here were almost all made in our laboratory, we have added some observations from the Deep Sea Drilling Project $x$-ray mineralogy laboratory, University of California at Riverside (Fan et al., this volume).

The major-element chemical composition of these sediments was also investigated. Essentially complete major element analyses (lacking $\mathrm{H}_{2} \mathrm{O}+, \mathrm{CO}_{2}$ ) were made of 91 samples mainly from Site $146 / 149$, and partial analyses were made of several others. Of special interest are the Paleocene siliceous clays of Site 146, the ferruginous clay at the unconformity of Site 148 , the $\mathrm{Mn}$ and Fe nodules and micronodules of Sites 150 and 153 , and the distinctive greenish Cretaceous clays of Sites 146, 151, and 153. At Site 146/149 analyses were made of 75 samples; the discussion of these analyses forms the major part of the chemical portion of this chapter.

\section{AUTHIGENIC MINERALOGY}

\section{Native Copper}

Copper was first identified in a pelagic clay sample whose severe disturbance from drilling consigned it for disposal (Sample 149-10-1). Sieving the soupy clay, however, produced a number of very small, metallic incrustations which appeared at first to be tarnished pyrite. Further inspection showed that the color was that of copper, the material was maleable with a needle, and it turned nitric acid green. A better preserved, washed and sieved sample (149-10, CC) was examined and several more pieces were found. Later investigation in the shore laboratory showed that this material gives the $\mathrm{x}$-ray diffraction pattern of native copper.

These copper crystals occurred as aggregates of 10 to 20 micron rough octahedra (Plate 1, Figure 5) on what appeared to be the inner surfaces of crude cylinders or irregular, globular bodies a fraction of a millimeter in diameter. Occurring with the copper were pyritized foraminifera, etched plagioclase, and quartz crystals.
The occurrence of elemental copper in pelagic clay poses a problem. The total chemical environment is unknown, but the inferred Eh and $p \mathrm{H}$ and low $\mathrm{P}_{\mathrm{CO}_{2}}$ would predict that copper might occur as a soluble positive ion. Further, the coexistence of pyrite and copper would not be predicted. We conclude tentatively that the copper was concentrated and precipitated organically, and that the form of the aggregates represents the lining of worm tubes or the coating of fecal pellets.

A survey of copper concentrations in several Leg 4 and Leg 15 sediments was undertaken (Figure 1; Tables 1,2). The values for copper from the late Tertiary pelagic clays and associated chalks and oozes are not untypical for pelagic clays in general. Apparently the occurrence of native copper in Sample 149-10 implies highly efficient organic concentration.

\section{Pyrite}

Pyrite is nearly ubiquitous in Site 147 and is widespread in Sites 148 and 154. Elsewhere pyrite occurs scattered in pelagic clay sequences, largely replacing foraminifera and Radiolaria (Plate 1, Figure 4), and, less commonly in lime or siliceous sequences. No serious study of pyrite was undertaken, but several problems are suggested by these occurrences.

The cooccurrence of pyrite and gypsum in the upper part of Site 153, in Site 154, and in Site 147 (Fan et al., this volume) is of interest. The good crystal form of the pyrite and the highly rounded and corroded appearance of the gypsum (especially in Site 154; not illustrated) suggests that in some instances pyrite forms secondarily from the reduction of sulfate minerals transported by turbidity currents.

Another problem that should be investigated is whether pyrite might form originally as metastable marcasite, which later inverts to pyrite. Notably elongate, rectangular crystals of an opaque mineral (presumably iron sulfide) were found in Site 154 (Sample 154A-4.4, 116) cooccurring with globular pyrite. These could originally have been marcasite; an x-ray diffraction trace of the sample showed only the pyrite.

\section{Anatase and Rutile}

Irregular, high refractive index, moderately high birefringent grains of very small size (invariably less than 10 microns) were found in almost all pelagic clays on this leg. A few samples showed the elongate octahedral form of anatase dipyramids (Plate 7, Figure 10), and much of this high-index material probably is this mineral. However, rutile is also very widespread, occurring typically as even smaller prismatic grains. There is no obvious textural criterion for determining whether rutile is a stable phase or is being dissolved and converted to anatase. 


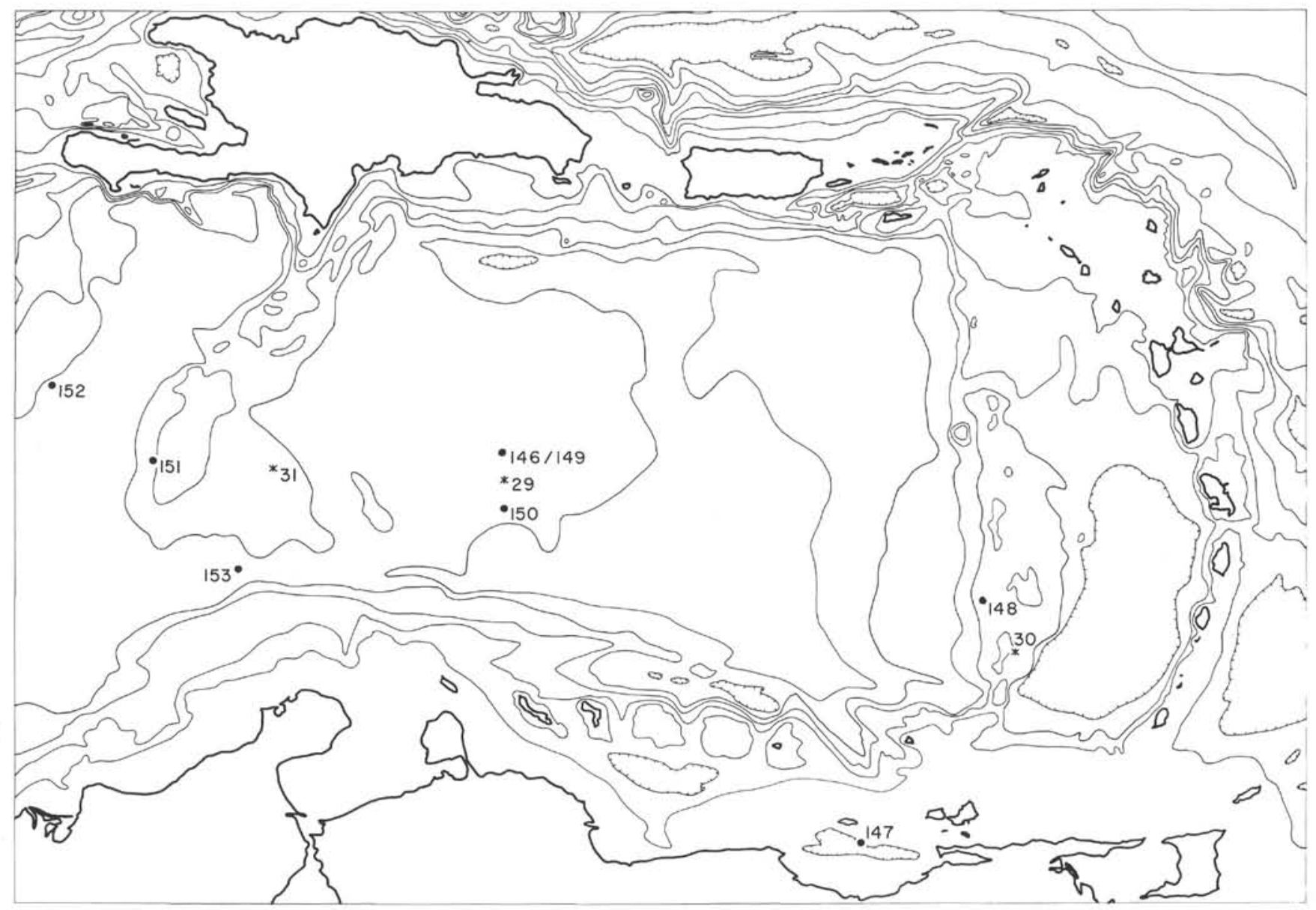

Figure 1. Index map of central Caribbean, showing Legs 4 and 15 sites.

\section{Dolomite and Siderite}

Dolomite is probably widespread in pelagic clays as a minor constituent, but its recognition poses a severe problem. Grain size is generally only about 5 microns or smaller (except in the case of the Site 147 dolomite beds). The grains are rhombohedral and, in theory, could be distinguished easily from calcite rhombohedra by their higher index of refraction. However, calcite rhombs commonly grow as pseudo-twinned aggregates of rhombs which lie on the smear slide with their c-axes vertical, showing a very high index of refraction in all orientations. Thus, extreme care must be exercised in the optical determination of dolomite. Recognition by x-ray diffraction also poses problems. The very minor amounts of dolomite in pelagic clays require concentration by dispersion and washing before $\mathrm{x}$-ray diffraction is attempted. Dispersion must be done with buffered water to avoid dissolving the dolomite; the small grain size, heat, and mechanical agitation of an ultrasonic probe will cause traces of pelagic dolomite to dissolve readily in ordinary tap or de-ionized water.

In pelagic clays dolomite may form as a replacement for nannofossil debris or otoliths. In the former case, it is instructive to note the gradual overgrowth of discoasters by calcite and their eventual conversion into pseudo-twinned rhombohedral aggregates (which may explain why so many lie with c-axes vertical). Dolomitization of this carbonate material may be the final phase of the destruction of nannoplankton debris.

In Sample 150-3 (CC), tiny, waxy spheroids aggregated in cylinders suggestive of worm tubes are possibly otoliths. These spheroids are completely composed of curved-crystal dolomite (Plate 1, Figure 3), suggesting replacement of original organic aragonite.

In Sample 153-4-3 (103) (Miocene) high index, high birefringent rhombohedra were found in a pelagic clay. No confirmation by $\mathrm{x}$-ray was made in this case. The crystals, however, showed a distinct pale yellow color in transmitted light, suggesting some iron or manganese content.

In highly organic sediments of the Cariaco Trench (Site 147), and again in the extreme southwestern Colombian Basin (Site 154), dolomite was found with pyrite. In Site 147 dolomite was especially prominent, forming nearly monomineralic beds (Site Report 147). In Site 154 dolomite was prominent in only one occurrence (Sample 154-10-1, 99). The beds of nearly pure dolomite in Site 147 (gypsum was also detected by x-ray diffraction, Fan et al., this volume) could represent a deep-water evaporite accumulation. At Site 154 dolomite is dispersed in a marl which resembles the clays at Site 147 in its high pyrite content and relatively high reduced carbon content. Similarities in the mineral associations at the two sites could indicate that dolomite is authigenic at each site. 
TABLE 1

Chemical Compositions of Sediments ${ }^{\mathrm{a}}$

\begin{tabular}{|c|c|c|c|c|c|c|c|c|c|c|c|c|c|c|c|}
\hline Sample & $\mathrm{SiO}_{2}$ & $\mathrm{TiO}_{2}$ & $\mathrm{Al}_{2} \mathrm{O}_{3}$ & $\mathrm{Fe}_{2} \mathrm{O}_{3}{ }^{2}$ & $\mathrm{MuO}$ & $\mathrm{MqO}$ & $\mathrm{CaO}$ & $\mathrm{Na}_{2} \mathrm{O}$ & $\mathrm{K}_{2} \mathrm{O}$ & $\mathrm{P}_{2} \mathrm{Q}_{5}$ & $\mathrm{Ba}$ & $\mathrm{Sr}$ & $\mathrm{Cu}$ & Sum & Lithology \\
\hline \multicolumn{16}{|l|}{ Site 146} \\
\hline $\begin{array}{l}1-4(28-29) \\
3(C C) \\
5-1(1-2) \\
5-2(29) \\
7-1(67)\end{array}$ & $\begin{array}{l}51.4 \\
79.7 \\
57.5 \\
66.3 \\
83.8\end{array}$ & $\begin{array}{l}0.83 \\
0.18 \\
0.69 \\
0.28 \\
0.22\end{array}$ & $\begin{array}{r}20.61 \\
4.31 \\
12.66 \\
6.91 \\
5.07\end{array}$ & $\begin{array}{l}8.48 \\
1.58 \\
3.19 \\
3.30 \\
2.16\end{array}$ & $\begin{array}{l}0.38 \\
0.13 \\
0.05 \\
0.03 \\
0.03\end{array}$ & $\begin{array}{l}2.52 \\
1.26 \\
4.62 \\
1.80 \\
1.34\end{array}$ & $\begin{array}{l}0.7 \\
0.6 \\
1.3 \\
2.3 \\
1.8\end{array}$ & $\begin{array}{l}2.06 \\
1.26 \\
3.49 \\
1.92 \\
1.28\end{array}$ & $\begin{array}{l}2.58 \\
0.88 \\
2.69 \\
1.32 \\
0.77\end{array}$ & $\begin{array}{l}0.21 \\
0.18 \\
0.14 \\
0.84 \\
0.86\end{array}$ & & & & $\begin{array}{l}89.8 \\
90.1 \\
86.3 \\
85.0 \\
97.3\end{array}$ & $\begin{array}{l}\text { Clay. } \\
\text { Chert. } \\
\text { Altered ash. } \\
\text { Siliceous clay. } \\
\text { Siliceous clay. }\end{array}$ \\
\hline $\begin{array}{l}7-1(80) \\
7(\mathrm{CC}) \\
8(\mathrm{CC}) \\
10-2(84-95) \\
10(\mathrm{CC})\end{array}$ & $\begin{array}{l}56.7 \\
21.6 \\
79.1 \\
81.9 \\
75.3\end{array}$ & $\begin{array}{l}1.17 \\
0.19 \\
0.24 \\
0.16 \\
0.53\end{array}$ & $\begin{array}{r}13.17 \\
4.21 \\
6.74 \\
4.52 \\
8.85\end{array}$ & $\begin{array}{l}6.67 \\
1.91 \\
2.65 \\
2.09 \\
3.18\end{array}$ & $\begin{array}{l}0.11 \\
0.34 \\
0.08 \\
0.09 \\
0.10\end{array}$ & $\begin{array}{l}4.76 \\
1.66 \\
1.89 \\
1.53 \\
1.62\end{array}$ & $\begin{array}{r}2.1 \\
31.5 \\
1.0 \\
0.9 \\
1.3\end{array}$ & $\begin{array}{l}3.16 \\
1.70 \\
1.66 \\
1.46 \\
1.47\end{array}$ & $\begin{array}{l}1.05 \\
0.60 \\
0.93 \\
0.50 \\
0.99\end{array}$ & $\begin{array}{l}0.14 \\
0.14 \\
0.22 \\
0.26 \\
0.15\end{array}$ & 5500 & 270 & 90 & $\begin{array}{l}89.1 \\
63.8 \\
94.5 \\
93.4 \\
93.5\end{array}$ & $\begin{array}{l}\text { Altered ash. } \\
\text { Chalk. } \\
\text { Siliceous clay. } \\
\text { Siliceous clay. } \\
\text { Siliceous clay. }\end{array}$ \\
\hline $\begin{array}{l}11-1(74-76) \\
11(C C) \\
12(C C) \\
13(C C) \\
14-1(95) \\
14-2(87-88) \\
15-2(143-144) \\
15-2(143-144)\end{array}$ & $\begin{array}{l}71.4 \\
37.4 \\
61.8 \\
15.9 \\
66.0 \\
49.6 \\
36.6 \\
41.2\end{array}$ & $\begin{array}{l}0.30 \\
0.34 \\
0.38 \\
0.35 \\
0.58 \\
0.48 \\
0.44 \\
0.48\end{array}$ & $\begin{array}{r}9.43 \\
5.61 \\
8.51 \\
7.39 \\
10.27 \\
10.13 \\
13.05 \\
13.36\end{array}$ & $\begin{array}{l}3.59 \\
3.26 \\
4.78 \\
2.93 \\
3.63 \\
4.61 \\
4.04 \\
3.98 \\
\end{array}$ & $\begin{array}{l}0.11 \\
0.32 \\
0.14 \\
0.21 \\
0.15 \\
0.15 \\
0.15 \\
0.06\end{array}$ & $\begin{array}{l}2.68 \\
2.25 \\
3.11 \\
2.70 \\
4.60 \\
3.53 \\
1.31 \\
3.66\end{array}$ & $\begin{array}{r}1.0 \\
22.2 \\
5.8 \\
22.8 \\
2.7 \\
13.3 \\
7.6 \\
7.6\end{array}$ & $\begin{array}{l}1.90 \\
0.89 \\
2.12 \\
0.94 \\
1.41 \\
1.66 \\
1.89 \\
2.10\end{array}$ & $\begin{array}{l}1.32 \\
1.01 \\
1.51 \\
1.06 \\
1.96 \\
1.59 \\
0.80 \\
0.88\end{array}$ & $\begin{array}{l}0.28 \\
0.14 \\
0.23 \\
0.14 \\
0.15 \\
0.06 \\
0.14 \\
0.14\end{array}$ & & & & $\begin{array}{l}92.0 \\
73.4 \\
88.4 \\
54.4 \\
91.4 \\
85.11 \\
66.0 \\
73.4\end{array}$ & $\begin{array}{l}\text { Siliceous clay. } \\
\text { Siliceous chalk. } \\
\text { Calcareous clay. } \\
\text { Chalk. } \\
\text { Altered ash. } \\
\text { Marl. } \\
\text { Marl. } \\
\text { Marl. }\end{array}$ \\
\hline $\begin{array}{l}15(C C) \\
1.6-3(9-10)\end{array}$ & $\begin{array}{l}16.0 \\
18.1\end{array}$ & $\begin{array}{l}0.20 \\
0.23\end{array}$ & $\begin{array}{l}3.68 \\
3.94\end{array}$ & $\begin{array}{l}1.68 \\
2.20\end{array}$ & $\begin{array}{l}0.13 \\
0.22\end{array}$ & $\begin{array}{l}1.25 \\
5.31\end{array}$ & $\begin{array}{l}37.2 \\
33.3\end{array}$ & $\begin{array}{l}0.34 \\
0.53\end{array}$ & $\begin{array}{l}0.60 \\
0.73\end{array}$ & $\begin{array}{l}0.14 \\
0.14\end{array}$ & & & & $\begin{array}{l}61.2 \\
64.7\end{array}$ & $\begin{array}{l}\text { Chalk. } \\
\text { Chalk. }\end{array}$ \\
\hline $\begin{array}{l}16-3(37.5-38.5) \\
16-6(75-76) \\
18-6 \text { frag. } \\
19(\mathrm{CC}) \\
20-2(99-100)\end{array}$ & $\begin{array}{l}51.11 \\
52.1 \\
18.0 \\
15.6 \\
22.5\end{array}$ & $\begin{array}{l}0.54 \\
0.74 \\
0.00 \\
0.17 \\
0.08\end{array}$ & $\begin{array}{r}18.42 \\
15.32 \\
1.31 \\
2.88 \\
1.85\end{array}$ & $\begin{array}{l}3.64 \\
3.23 \\
0.06 \\
1.15 \\
0.47\end{array}$ & $\begin{array}{l}0.06 \\
0.03 \\
0.09 \\
0.13 \\
0.08\end{array}$ & $\begin{array}{l}5.38 \\
4.25 \\
4.57 \\
0.84 \\
0.811\end{array}$ & $\begin{array}{r}1.5 \\
7.5 \\
45.4 \\
38.1 \\
41.2\end{array}$ & $\begin{array}{l}2.47 \\
2.19 \\
0.62 \\
0.25 \\
0.77\end{array}$ & $\begin{array}{l}0.48 \\
1.41 \\
0.18 \\
0.49 \\
0.31\end{array}$ & $\begin{array}{l}0.14 \\
0.06 \\
0.04 \\
0.14 \\
0.04\end{array}$ & & & & $\begin{array}{l}83.7 \\
86.9 \\
70.3 \\
59.7 \\
68.1\end{array}$ & $\begin{array}{l}\text { Altered ash. } \\
\text { Altered ash. } \\
\text { Limestome. } \\
\text { Chalk. } \\
\text { Siliceous chalk. }\end{array}$ \\
\hline $\begin{array}{l}20(C C) \\
21(C C) \\
23-2(93-94) \\
23-3(5-6) \\
14(C C)\end{array}$ & $\begin{array}{r}9.6 \\
4.6 \\
43.2 \\
36.5 \\
58.8\end{array}$ & $\begin{array}{l}0.15 \\
0.16 \\
0.46 \\
0.61 \\
0.21\end{array}$ & $\begin{array}{r}2.47 \\
2.35 \\
17.73 \\
18.20 \\
4.05\end{array}$ & $\begin{array}{l}1.10 \\
1.15 \\
4.33 \\
4.93 \\
1.82\end{array}$ & $\begin{array}{l}0.12 \\
0.07 \\
0.04 \\
0.06 \\
0.12\end{array}$ & $\begin{array}{l}0.79 \\
0.82 \\
5.12 \\
4.91 \\
1.31\end{array}$ & $\begin{array}{r}42.1 \\
44.1 \\
1.8 \\
1.5 \\
12.6\end{array}$ & $\begin{array}{l}0.16 \\
0.14 \\
2.26 \\
2.31 \\
0.45\end{array}$ & $\begin{array}{l}0.41 \\
0.34 \\
0.71 \\
0.76 \\
0.78\end{array}$ & $\begin{array}{l}0.14 \\
0.14 \\
0.14 \\
0.14 \\
0.14\end{array}$ & & & & $\begin{array}{l}47.0 \\
53.9 \\
76.8 \\
69.9 \\
80.2\end{array}$ & $\begin{array}{l}\text { Chalk. } \\
\text { Chalk. } \\
\text { Altered ash. } \\
\text { Altered ash. } \\
\text { Marl. }\end{array}$ \\
\hline $\begin{array}{l}25(C C) \\
26(C C) \\
27(C C) \\
27(C C) \\
28(C C)\end{array}$ & $\begin{array}{l}17.8 \\
19.6 \\
63.0 \\
54.0 \\
19.1\end{array}$ & $\begin{array}{l}0.08 \\
0.19 \\
0.10 \\
0.45 \\
0.10\end{array}$ & $\begin{array}{l}1.04 \\
3.14 \\
3.90 \\
5.10 \\
1.17\end{array}$ & $\begin{array}{l}0.51 \\
1.23 \\
0.90 \\
1.50 \\
0.24\end{array}$ & $\begin{array}{l}0.09 \\
0.13 \\
0.08 \\
0.06 \\
0.14\end{array}$ & $\begin{array}{l}1.41 \\
1.07 \\
1.90 \\
0.70 \\
0.35\end{array}$ & $\begin{array}{l}35.1 \\
33.3 \\
16.4 \\
17.9 \\
35.7\end{array}$ & $\begin{array}{l}0.06 \\
0.26 \\
0.70 \\
1.10 \\
0.01\end{array}$ & $\begin{array}{l}0.01 \\
0.54 \\
0.70 \\
0.75 \\
0.23\end{array}$ & $\begin{array}{l}0.14 \\
0.14 \\
0.09 \\
0.17 \\
0.13\end{array}$ & $\begin{array}{l}2700 \\
2800\end{array}$ & $\begin{array}{r}1400 \\
600\end{array}$ & $\begin{array}{l}20 \\
70\end{array}$ & $\begin{array}{l}56.2 \\
59.6 \\
88.1 \\
83.4 \\
57.2\end{array}$ & $\begin{array}{l}\text { Chalk. } \\
\text { Chalk. } \\
\text { Marl. } \\
\text { Marl. } \\
\text { Radiolarian limestone. }\end{array}$ \\
\hline $\begin{array}{l}30(\mathrm{CC}) \\
31(\mathrm{CC}) \\
32(\mathrm{CC}) \\
33(\mathrm{CC}) \\
34-1(51-56)\end{array}$ & $\begin{array}{r}12.4 \\
48.7 \\
15.4 \\
6.1 \\
55.3\end{array}$ & $\begin{array}{l}0.08 \\
0.12 \\
0.111 \\
0.11 \\
0.90\end{array}$ & $\begin{array}{r}1.08 \\
1.77 \\
2.21 \\
0.74 \\
14.90\end{array}$ & $\begin{array}{l}0.29 \\
1.16 \\
1.06 \\
1.02 \\
7.00\end{array}$ & $\begin{array}{l}0.12 \\
0.12 \\
0.10 \\
0.09 \\
0.02\end{array}$ & $\begin{array}{l}0.16 \\
0.36 \\
2.74 \\
0.39 \\
5.90\end{array}$ & $\begin{array}{r}36.9 \\
28.2 \\
37.2 \\
38.7 \\
2.4\end{array}$ & $\begin{array}{l}0.01 \\
0.29 \\
0.15 \\
0.01 \\
2.35\end{array}$ & $\begin{array}{l}0.06 \\
0.32 \\
0.38 \\
0.23 \\
1.65\end{array}$ & $\begin{array}{l}0.13 \\
0.14 \\
0.13 \\
0.14 \\
0.13\end{array}$ & 750 & 250 & 90 & $\begin{array}{l}51.2 \\
81.2 \\
59.4 \\
47.5 \\
90.6\end{array}$ & $\begin{array}{l}\text { Radiolarian limestone } \\
\text { Siliceous limestone. } \\
\text { Radiolarian limestone. } \\
\text { Radiolarian limestone. } \\
\text { Altered ash. }\end{array}$ \\
\hline $\begin{array}{l}35 \text {-frag. } \\
36(\mathrm{CC}) \\
36(\mathrm{CC}) \\
38(\mathrm{CC})\end{array}$ & $\begin{array}{r}5.6 \\
60.5 \\
47.5 \\
47.9\end{array}$ & $\begin{array}{l}0.23 \\
0.35 \\
0.41 \\
0.15\end{array}$ & $\begin{array}{l}4.74 \\
3.45 \\
6.60 \\
1.69\end{array}$ & $\begin{array}{l}2.77 \\
1.92 \\
3.33 \\
0.91\end{array}$ & $\begin{array}{l}0.29 \\
0.04 \\
0.11 \\
0.10\end{array}$ & $\begin{array}{l}1.16 \\
0.62 \\
1.85 \\
0.21\end{array}$ & $\begin{array}{r}38.7 \\
15.2 \\
6.4 \\
19.5\end{array}$ & $\begin{array}{l}0.40 \\
0.41 \\
0.97 \\
0.09\end{array}$ & $\begin{array}{l}0.43 \\
0.63 \\
1.07 \\
0.41\end{array}$ & $\begin{array}{l}0.14 \\
0.14 \\
0.15 \\
0.14\end{array}$ & & & & $\begin{array}{l}54.5 \\
83.2 \\
68.4 \\
71.1\end{array}$ & $\begin{array}{l}\text { Radiolarian limestone. } \\
\text { Siliceous limestone. } \\
\text { Siliceous limestone. } \\
\text { Siliceous limestone. }\end{array}$ \\
\hline $\begin{array}{l}38(\mathrm{CC}) \\
39 \mathrm{R}-2(76-80) \\
39 \mathrm{R}-2(76-80) \\
39 \mathrm{R}-2(125-126\end{array}$ & $\begin{array}{l}51.9 \\
48.3 \\
53.5 \\
47.7\end{array}$ & $\begin{array}{l}0.57 \\
1.60 \\
1.15 \\
1.56\end{array}$ & $\begin{array}{l}12.23 \\
13.60 \\
11.10 \\
11.35\end{array}$ & $\begin{array}{r}6.84 \\
12.50 \\
10.10 \\
11.14\end{array}$ & $\begin{array}{l}0.09 \\
0.08 \\
0.09 \\
0.15\end{array}$ & $\begin{array}{l}4.97 \\
8.40 \\
6.40 \\
6.78\end{array}$ & $\begin{array}{l}7.6 \\
4.1 \\
4.4 \\
7.2\end{array}$ & $\begin{array}{l}2.07 \\
3.50 \\
2.25 \\
1.94\end{array}$ & $\begin{array}{l}0.50 \\
0.95 \\
2.30 \\
1.20\end{array}$ & $\begin{array}{l}0.15 \\
0.12 \\
0.16 \\
0.14\end{array}$ & $\begin{array}{r}50 \\
1100\end{array}$ & $\begin{array}{l}150 \\
140\end{array}$ & $\begin{array}{l}300 \\
210\end{array}$ & $\begin{array}{l}86.9 \\
93.2 \\
91.6 \\
88.1\end{array}$ & $\begin{array}{l}\text { Altered ash. } \\
\text { Basaltic ash. } \\
\text { Green clay. } \\
\text { Basaltic ash. }\end{array}$ \\
\hline $\begin{array}{l}\text { Site } 148 \\
27(C C)\end{array}$ & 27.2 & 1.0 & 7.5 & 42.6 & 0.26 & 1.6 & 0.9 & 1.55 & 1.05 & 1.21 & 150 & 30 & 150 & 84.9 & Ferruginous clay. \\
\hline \multicolumn{16}{|l|}{ Site 149} \\
\hline $\begin{array}{l}2-1(107-108) \\
3-1(146-147) \\
4-1(82-83) \\
7-1(74-75) \\
10-1(119-120)\end{array}$ & $\begin{array}{l}18.0 \\
18.11 \\
26.2 \\
28.5 \\
50.2\end{array}$ & $\begin{array}{l}0.28 \\
0.28 \\
0.40 \\
0.44 \\
0.80\end{array}$ & $\begin{array}{r}6.75 \\
6.70 \\
10.42 \\
11.14 \\
22.10\end{array}$ & $\begin{array}{l}2.71 \\
2.50 \\
4.00 \\
4.18 \\
8.10\end{array}$ & $\begin{array}{l}0.21 \\
0.33 \\
0.16 \\
0.28 \\
0.71\end{array}$ & $\begin{array}{l}1.50 \\
1.37 \\
1.59 \\
1.38 \\
2.50\end{array}$ & $\begin{array}{r}36.8 \\
38.2 \\
29.6 \\
27.8 \\
1.2\end{array}$ & $\begin{array}{l}2.08 \\
1.72 \\
2.05 \\
1.67 \\
2.10\end{array}$ & $\begin{array}{l}0.81 \\
0.83 \\
1.18 \\
1.46 \\
2.45\end{array}$ & $\begin{array}{l}0.07 \\
0.05 \\
0.07 \\
0.07 \\
0.19\end{array}$ & 350 & 80 & 50 & $\begin{array}{l}69.2 \\
70.1 \\
75.7 \\
76.9 \\
90.4\end{array}$ & $\begin{array}{l}\text { Chalk ooze. } \\
\text { Chalk ooze. } \\
\text { Chalk ooze. } \\
\text { Chalk ooze. } \\
\text { Clay. }\end{array}$ \\
\hline $\begin{array}{l}10-2(43-44) \\
10-3(20-21) \\
10-5(53-54) \\
10(C C) \\
13-1(82-83)\end{array}$ & $\begin{array}{l}50.7 \\
49.5 \\
50.3 \\
51.7 \\
51.1\end{array}$ & $\begin{array}{l}0.80 \\
0.80 \\
0.80 \\
0.85 \\
0.81\end{array}$ & $\begin{array}{l}22.80 \\
21.30 \\
21.70 \\
22.30 \\
20.25\end{array}$ & $\begin{array}{l}8.00 \\
8.40 \\
8.20 \\
7.70 \\
8.19\end{array}$ & $\begin{array}{l}0.50 \\
0.69 \\
0.64 \\
0.16 \\
0.72\end{array}$ & $\begin{array}{l}2.50 \\
2.40 \\
2.50 \\
2.40 \\
2.87\end{array}$ & $\begin{array}{l}1.3 \\
1.3 \\
1.4 \\
0.7 \\
2.1\end{array}$ & $\begin{array}{l}2.35 \\
2.15 \\
2.05 \\
2.10 \\
2.25\end{array}$ & $\begin{array}{l}2.40 \\
2.40 \\
2.40 \\
2.40 \\
2.47\end{array}$ & $\begin{array}{l}0.23 \\
0.21 \\
0.17 \\
0.14 \\
0.22\end{array}$ & $\begin{array}{l}400 \\
400 \\
400 \\
450\end{array}$ & $\begin{array}{l}80 \\
50 \\
70 \\
90\end{array}$ & $\begin{array}{l}40 \\
40 \\
60 \\
60\end{array}$ & $\begin{array}{l}90.6 \\
89.2 \\
90.2 \\
90.5 \\
91.0\end{array}$ & $\begin{array}{l}\text { Clay. } \\
\text { Clay. } \\
\text { Clay. } \\
\text { Clay. } \\
\text { Clay. }\end{array}$ \\
\hline
\end{tabular}


TABLE 1 - Continued

\begin{tabular}{|c|c|c|c|c|c|c|c|c|c|c|c|c|c|c|c|}
\hline Sample & $\mathrm{SiO}_{2}$ & $\mathrm{TiO}_{2}$ & $\mathrm{Al}_{2} \mathrm{O}_{3}$ & $\mathrm{Fe}_{2} \mathrm{O}_{3}{ }^{2}$ & $\mathrm{MuO}$ & $\mathrm{MqO}$ & $\mathrm{CaO}$ & $\mathrm{Na}_{2} \mathrm{O}$ & $\mathrm{K}_{2} \mathrm{O}$ & $\mathrm{P}_{2} \mathrm{O}_{5}$ & $\mathrm{Ba}$ & $\mathrm{Sr}$ & $\mathrm{Cu}$ & Sum & Lithology \\
\hline $16-1(75-76)$ & 54.0 & 0.78 & 20.12 & 8.57 & 0.72 & 2.52 & 0.8 & 2.11 & 2.50 & 0.10 & & & & 92.2 & Clay. \\
\hline $19-2(72-73)$ & 18.4 & 0.18 & 4.62 & 1.74 & 0.29 & 0.89 & 38.3 & 1.54 & 0.97 & 0.04 & & & & 67.5 & Chalk. \\
\hline $21-1(123-124)$ & 19.5 & 0.22 & 7.38 & 3.36 & 0.25 & 1.37 & 33.3 & 1.57 & 0.81 & 0.04 & & & & 67.5 & Chalk. \\
\hline $23-2(59-60)$ & 18.4 & 0.24 & 6.49 & 2.90 & 0.20 & 1.24 & 33.5 & 1.75 & 1.12 & 0.04 & & & & 65.9 & Chalk. \\
\hline $25-3(74-75)$ & 13.3 & 0.14 & 3.72 & 1.44 & 0.27 & 0.93 & 43.6 & 1.20 & 0.42 & 0.11 & & & & 65.1 & Chalk. \\
\hline $28-1(99-100)$ & 37.6 & 0.39 & 10.40 & 4.57 & 0.16 & 2.09 & 21.1 & 2.64 & 1.16 & 0.22 & & & & 80.3 & Radiolarian chalk. \\
\hline $29-2(149-150)$ & 27.3 & 0.26 & 5.63 & 2.70 & 0.25 & 1.19 & 34.0 & 1.69 & 0.60 & 0.06 & & & & 73.7 & Radiolarian chalk. \\
\hline $30-2(78-79)$ & 35.2 & 0.30 & 8.10 & 3.20 & 0.20 & 1.86 & 26.6 & 1.93 & 1.00 & 0.12 & & & & 78.5 & Radiolarian chalk. \\
\hline $3 \cdot 1-2(124-125)$ & 53.5 & 0.26 & 7.24 & 3.10 & 0.22 & 1.56 & 9.6 & 2.96 & 0.92 & 0.22 & & & & 80.6 & Radiolarian ooze. \\
\hline $32-2(123-124)$ & 54.5 & 0.26 & 6.87 & 2.87 & 0.12 & 1.43 & 10.8 & 2.70 & 0.76 & 0.25 & & & & 80.6 & Radiolarian ooze. \\
\hline $33-1(54-55)$ & 67.6 & 0.26 & 6.18 & 2.63 & 0.14 & 1.27 & 5.1 & 2.95 & 0.73 & 0.18 & & & & 87.0 & Radiolarian ooze. \\
\hline $34-3(81-82)$ & 53.8 & 0.08 & 3.12 & 1.04 & 0.16 & 0.85 & 22.1 & 2.05 & 0.44 & 0.10 & & & & 83.6 & Radiolarian chalk, \\
\hline $37-3(86-87)$ & 44.0 & 0.08 & 2.77 & 0.94 & 0.19 & 0.86 & 26.5 & 1.79 & 0.38 & 0.07 & & & & 77.6 & Radiolarian chalk, \\
\hline $38-1(143-144)$ & 61.8 & 0.12 & 3.49 & 1.19 & 0.09 & 1.14 & 10.5 & 2.74 & 0.54 & 0.09 & & & & 81.7 & Radiolarian ooze. \\
\hline $40-2(14-15)$ & 53.5 & 0.08 & 2.80 & 0.89 & 0.15 & 0.84 & 19.5 & 2.19 & 0.44 & 0.09 & & & & 80.5 & Radiolarian chalk. \\
\hline $41-3(136-137$ & 50.1 & 0.08 & 2.74 & 0.94 & 0.16 & 0.90 & 21.8 & 2.06 & 0.35 & 0.11 & & & & 79.2 & Radiolarian chalk. \\
\hline $42-2(40-11)$ & 46.0 & 0.10 & 2.90 & 1.17 & 0.17 & 1.00 & 23.6 & 2.13 & 0.48 & 0.12 & & & & 77.7 & Radiolarian chalk. \\
\hline \multicolumn{16}{|l|}{ Site 150} \\
\hline $2-1(45-46)$ & 44.3 & 0.80 & 22.7 & & 0.12 & 2.1 & 0.4 & 2.05 & 2.55 & 0.15 & 400 & 30 & 60 & 87.9 & Clay. \\
\hline $3-1(132-133)$ & 50.4 & 0.85 & 21.2 & 10.7 & 0.30 & 2.3 & 0.6 & 2.45 & 2.50 & 0.14 & 350 & 30 & 50 & 91.4 & Clay. \\
\hline $4-1(70-71)$ & 51.4 & 0.75 & 20.3 & 8.2 & 0.87 & 2.7 & 1.1 & 2.85 & 2.20 & 0.38 & 300 & 60 & 70 & 90.3 & Clay. \\
\hline \multirow[t]{2}{*}{$5-1(114-115)$} & \multirow[t]{3}{*}{42.8} & \multirow[t]{3}{*}{0.55} & \multirow[t]{3}{*}{14.5} & \multirow[t]{2}{*}{6.3} & \multirow[t]{2}{*}{0.39} & \multirow[t]{3}{*}{2.5} & \multirow[t]{3}{*}{10.5} & \multirow[t]{3}{*}{2.55} & \multirow[t]{3}{*}{1.75} & \multirow[t]{2}{*}{0.20} & $\begin{array}{r}750 \\
18000\end{array}$ & 340 & $\begin{array}{r}80 \\
1600\end{array}$ & 82.1 & \multirow{3}{*}{$\begin{array}{l}\text { Zeolitic clay. } \\
\text { Micronodules } \\
\text { (1 mq. sample) } \\
\text { Iron-manganese } \\
\text { nodule. }\end{array}$} \\
\hline & & & & & & & & & & & & & & & \\
\hline $5-3(76-77)$ & & & & 2.5 & 53 & & & & & & 750 & 160 & 550 & 83.9 & \\
\hline $5-4(42-43)$ & 38.5 & 1.05 & 8.9 & 23.7 & 4.6 & 1.3 & 1.7 & 2.55 & 1.30 & 0.18 & 1200 & 430 & 700 & 80.8 & Iron-manganese \\
\hline $5(\mathrm{CC})$ & 49.3 & 0.60 & 13.8 & 6.8 & 0.70 & 2.9 & 6.7 & 3.05 & 2.50 & 0.45 & 2700 & 310 & 210 & 87.1 & Zeolitic clay. \\
\hline $2(\mathrm{CC})$ & 56.8 & 0.50 & 13.45 & 5.04 & 0.16 & 4.26 & 2.99 & 3.45 & 2.21 & 0.92 & & & & 89.78 & Zeolitic clay. \\
\hline $12-1$ frag. & 89.9 & 0.00 & 1.45 & 5.70 & 0.04 & 0.37 & 0.22 & 0.10 & 0.28 & 0.04 & & & & 98.10 & Chert (?hard ground) \\
\hline 13-1 frag. & 92.3 & 0.10 & 0.8 & 3.9 & 0.03 & 0.3 & 1.5 & 0.10 & 0.15 & 0.07 & 50 & 20 & 10 & 99.3 & Chert (?hard ground) \\
\hline $13-2(67-68)$ & 53.6 & 0.82 & 12.89 & 12.44 & 0.05 & 3.37 & 0.78 & 1.49 & 7.26 & 0.04 & & & & 92.74 & Green clay. \\
\hline $2(\mathrm{CC})$ & & & & 20 & 46 & & & & & & 22,000 & 2000 & 200 & & $\begin{array}{l}\text { Micronodules } \\
\text { (1 mg. sample) }\end{array}$ \\
\hline $4-1(9-11)$ & 53.0 & 0.53 & 18.64 & 6.74 & 0.04 & 2.32 & 1.70 & 2.09 & 3.14 & 0.04 & & & & 88.2 & Clay. \\
\hline $16-2(68-69)$ & 55.9 & 0.45 & 4.9 & 2.5 & 0.04 & 0.08 & 8.6 & 1.30 & 0.70 & 0.82 & 1200 & 450 & 200 & 76.1 & Carbonaceous clay. \\
\hline $17-1(121-129)$ & 48.7 & 0.85 & 12.6 & 8.0 & 0.04 & 5.5 & 7.0 & 2.50 & 0.70 & 0.12 & 1900 & 500 & 110 & 86.2 & Basaltic, carbona- \\
\hline $18-3(10-13)$ & 41.7 & 0.98 & 10.78 & 10.05 & 0.17 & 6.35 & 9.83 & 1.83 & 3.21 & 0.08 & & & & 85.0 & $\begin{array}{l}\text { Basaltic, carbona- } \\
\text { ceous clay. }\end{array}$ \\
\hline
\end{tabular}

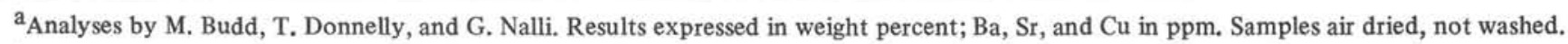

b ${ }_{\mathrm{T}}$ tal iron as $\mathrm{Fe}_{2} \mathrm{O}_{3}$.

Oxidation of organic matter would be expected to raise the $\mathrm{P}_{\mathrm{CO}_{2}}$, and the abundance of pyrite suggests that $\mathrm{Mg}$-ion activity might have been raised by the breakdown of $\mathrm{Mg}-\mathrm{Fe}$ silicates during pyrite formation. At Site 148 dispersed high-refractive index rhombs are siderite. These are more likely authigenic and their occurrence with pyrite reflects high ferrous-ion activity.

\section{Cristobalite-Quartz; Chert Micronodules}

As has been noted repeatedly, cristobalite is the almost ubiquitous recrystallization product of organic opaline debris in siliceous sediments of early Tertiary age in the deep seas. In Site 146/149, cristobalite appeared abruptly in the middle Eocene (Sample 146-3, CC) as a very hard chert (Horizon A") and continued to dominate the sedimentary mineralogy through the Paleocene (Figure 2). These siliceous clays, which are interlayered with chalks, have high $\mathrm{SiO}_{2}$ contents (Table 1, sample analyses from 146-5 through 146-16). X-ray diffraction commonly shows only cristobalite and montmorillonite, with some minor clinoptilolite, in this interval. Interestingly, perhaps, these soft clays and semi-hard ashes have $\mathrm{SiO}_{2}$ values as high or only slightly lower than the extremely hard chert from Sample 146-3, CC. Lithification does not necessarily imply a marked increase in the silica content, on a dry weight percent basis.

Though the entire Paleocene-Lower Eocene section has the appearance of silicified volcanic debris, the occurrence of abundant radiolarian remains through this interval is notable. In several cristobalite clays, smear slides reveal the 
TABLE 2

Partial Chemical Analyses of Late Tertiary Clays, Chalks, and Oozes from the Central Caribbean ${ }^{2}$

\begin{tabular}{|c|c|c|c|c|c|}
\hline Leg & $\begin{array}{l}\text { Site, Core, } \\
\text { Interval } \\
\text { (m) }\end{array}$ & Lith. & $\mathrm{MnO}$ & $\mathrm{P}_{2} \mathrm{O}_{5}$ & $\underset{(\mathrm{ppm})}{\mathrm{Cu}}$ \\
\hline 4 & $29-31(46-47)$ & Clay & 0.23 & 0.23 & 46 \\
\hline 4 & $29-41(105-106)$ & Clay & 0.21 & 0.26 & 62 \\
\hline 4 & $29-51(49-50)$ & Clay & 0.16 & 0.29 & 82 \\
\hline 4 & $29-61(23-24)$ & Clay & 0.59 & 0.30 & 82 \\
\hline 4 & $29-71(144-145)$ & Chalk & 0.22 & 0.18 & 46 \\
\hline 4 & $31-51(58-59)$ & Ooze & 0.19 & 0.17 & 42 \\
\hline 4 & $31-62(45-46)$ & Ooze & 0.31 & 0.24 & 78 \\
\hline 4 & $31-71(131-132)$ & Ooze & 0.18 & 0.23 & 46 \\
\hline 4 & $31-81(86-87)$ & Chalk & 0.23 & 0.18 & 42 \\
\hline 4 & $31-91(141-146)$ & Chalk & 0.13 & 0.18 & 22 \\
\hline 15 & $149-82(144-145)$ & Clay & 0.30 & 0.21 & 32 \\
\hline 15 & $149-94(55-56)$ & Clay & 0.30 & 0.20 & 42 \\
\hline 15 & $149-116(19-20)$ & Clay & 0.42 & 0.26 & 66 \\
\hline 15 & $149-151(89-90)$ & Clay & 0.56 & 0.24 & 120 \\
\hline 15 & $149-165(80-81)$ & Chalk & 0.32 & 0.15 & 46 \\
\hline 15 & $150-22(25-26)$ & Clay & 0.53 & 0.28 & 46 \\
\hline 15 & $150-32(105-106)$ & Clay & 0.11 & 0.26 & 48 \\
\hline 15 & $150-41(70-71)$ & Clay & 0.22 & 0.09 & 32 \\
\hline 15 & $150-51(114-115)$ & Clay & 0.49 & 0.34 & 78 \\
\hline 15 & $151-21(140-141)$ & Chalk & 0.07 & 0.19 & 32 \\
\hline 15 & $151-32(79-80)$ & Chalk & 0.11 & 0.17 & 20 \\
\hline 15 & $151-41(107-108)$ & Chalk & 0.09 & 0.12 & 206 \\
\hline $15-$ & $151-52(30-31)$ & Chalk & 0.06 & 0.11 & 48 \\
\hline
\end{tabular}

${ }^{a}$ Analyses by G. Nalli and R. Horton.

presence of globular cristobalite grains which are evidently filled and/or replaced Radiolaria (Plate 3, Figure 5). In the Maestrichtian, cristobalite dissapears and all $\mathrm{x}$-ray diffraction records of silica below this are of quartz.

Throughout the Paleocene and late Cretaceous sections of Site 146 and, to a lesser extent, in coeval sections at other sites, chert micronodules are conspicuous. These invariably are filled and/or coated radiolarians, and the good preservation often allows generic determination. The Paleocene micronodules are commonly poorly defined globules of cristobalite. The Cretaceous examples are chalcedonic quartz, commonly coated with calcite crystals. One of the most remarkable occurrences of these micronodules is as sandy layers concentrated as turbidites within the Cretaceous portion of Site 146 (Site Report 146). These turbidite intercalations contain no other material and were evidently derived through the erosion of radiolarian debris from topographic highs within the basin.

\section{K-Feldspar}

Authigenic K-feldspar was found in samples from five sites. It is distinguished readily from volcanic alkali feldspar by crystal morphology, lower index of refraction, and by the presence of abundant inclusions of clay. Authigenic $\mathrm{K}$-feldspar could be confused with volcanic alkali feldspar, though the latter (which commonly cooccurs with quartz and biotite) is generally clear, occurs as anhedral grains, and shows a low optic angle. Crystals of authigenic K-feldspar (Plate 7, Figures 1-6) are invariably flattened on $\{010\}$, with prominent $\{001\}$, less prominent $\{101\}$, and small $\{201\}$ and $\{110\}$ faces. These crystals have a very low extinction angle $\begin{array}{llll}146 / 149 & 150 & 151 & 152\end{array}$

153

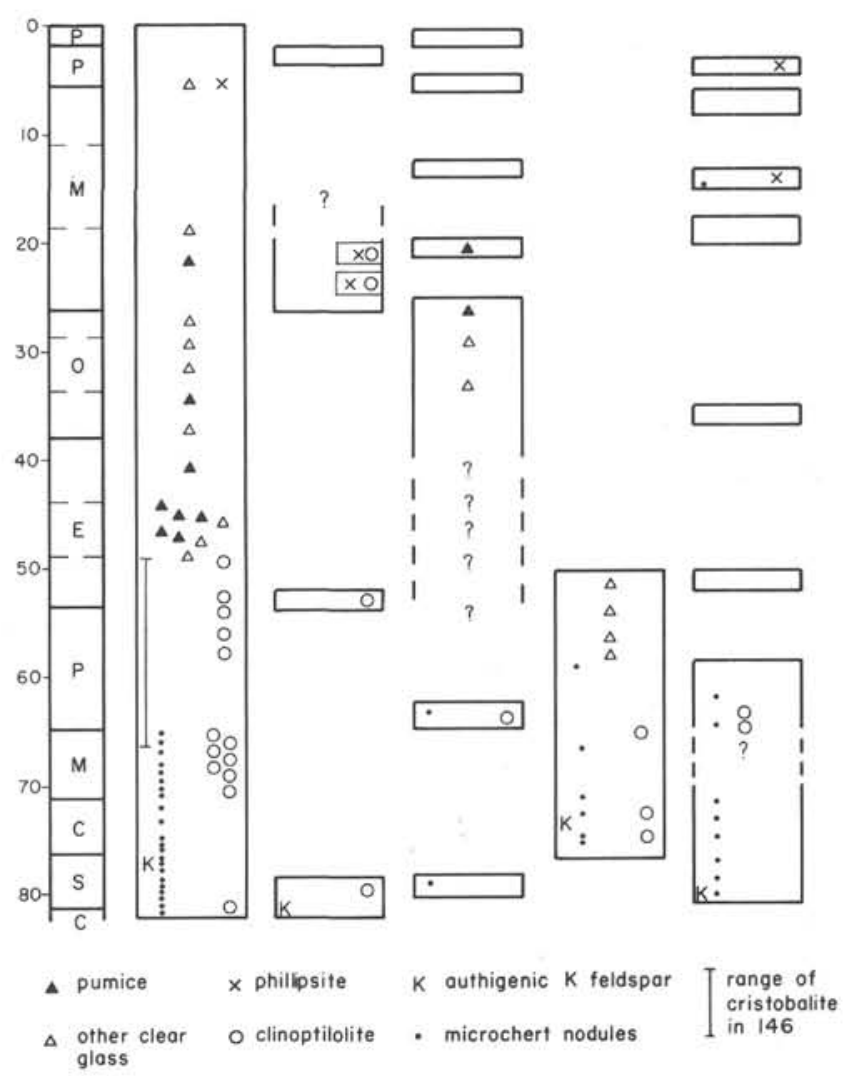

Figure 2. Cores with occurrences of volcanic glass, chert micronodules, and authigenic silicates in the central Caribbean. Times in millions of years, and stratigraphic time scale (mainly from Berggren, 1969) shown at left. Abbreviations: $P=$ Pliocene, $M=$ Miocene, $O=$ Oligocene, $E=$ Eocene, $P=$ Paleocene, $M=$ Maestrichtian, $C=$ Campanian, $S=$ Santonian, $C=$ Coniacian. Note that additional minor zeolite occurrences have been detected by $x$-ray diffraction (Chapter 14).

$\underline{X}_{\wedge}$ a on $(010)$ and $n_{x}=1.518$, characteristic of nearly pure $\mathrm{K}$-feldspar. The optic axial plane is perpendicular to (010); the normal to (010) is an obtuse bisectrix. Trains of inclusions forming ragged lines parallel to the c-axis are evident in most samples, although only one example showed these clearly in a photograph (Plate 7, Figure 1). These represent previous positions of 110 faces which were overgrown, leaving attached sediment entrapped.

In several samples from Site 154 (Cores 4, 5, 6, 10, and 13) and Hole 154A $(1,4,17$, and 18), both in the pelagic sequence and in the turbidite sequence, prominent alkali feldspar peaks were seen on x-ray diffraction tracings, along with peaks indicating plagioclase, phillipsite, and other minerals. Smear slides showed only plagioclase crystals, more or less abundant phillipsite, and tiny, high negative relief, colorless, formless shreds. By a process of elimination these shreds are considered probably to be authigenic $\mathrm{K}$-feldspar, and the association between this mineral and 
phillipsite may be more widespread than has been recognized.

Two occurrences of authigenic K-feldspar show an association with basaltic volcanism (Samples 150-10-2, 100, and 153-18-2, 10-15, both Coniacian). Others may be related to calc-alkaline activity (Samples 146-31-2, 120, Santonian; 152-18-2, 60, Maestrichtian; and the occurrences at Site 154).

\section{Phillipsite, Clinoptilolite, and Volcanic Glass}

Phillipsite (Plate 5, Figures 1-4, 6) and clinoptilolite (Plate 5, Figures 5, 6; Plate 6, Figures 1-9) are not always easily distinguished optically. Phillipsite commonly forms larger crystals than clinoptilolite. Large grains are evidently multiply twinned about the long axis of the crystal and form pseudo-tetragonal prisms with characteristic acutely angled terminations. These prisms may be complexly intergrown, but only one or two doubtful occurrences of cruciform interpenetrating twins of this form were noted in the entire Leg. Very thin phillipsite prisms (Plate 5, Figure 4) may not be twinned; the very low birefringence makes optical criteria for establishing the existence of twins inapplicable.

Clinoptilolite commonly forms very small, ragged (Plate 6, Figures 3, 9) to subhedral (Plate 6, Figures 1, 2; Plate 5, Figure 5) grains. In cooccurrences with phillipsite (Plate 5, Figure 6) it is the finer grained mineral. In two occurrences (Samples 150-9-1, 118, Santonian, and 152-10, $\mathrm{CC}$, Paleocene) clinoptilolite occurs as large, well- formed crystals. These crystals are flattened on 101 and give a poor acute bisectrix figure with an apparently low negative $2 \mathrm{~V}$.

The first nine legs of the Deep Sea Drilling Project recovered both of these zeolites (and one occurrence of erionite on Leg 6) at many localities. As shown in Figure 3, the Atlantic and Caribbean legs (1-4) recorded abundant clinoptilolite in the middle and early Tertiary, and in scattered occurrences in the Cretaceous and late Tertiary. Phillipsite was recorded only in a few late Tertiary and one Cretaceous occurrence. In the Pacific legs (5-9) phillipsite was conspicuous, especially in the late Tertiary but as far back as middle Tertiary. Clinoptilolite was more limited on these legs, occurring most conspicuously in the middle and early Tertiary, occurring also in the Cretaceous, and, less commonly in the late Tertiary. As a general rule the increased abundance of clinoptilolite in older sediments and phillipsite in younger sediments is apparent. Cooccurrences of the two minerals were noted in Leg 6 and Leg 9 (Rex et al., 1971). Figure 3 shows the zeolite occurrences of Leg 15 as reported by the Deep Sea Drilling Project x-ray mineralogy laboratory, and Figure 2 shows the results from out laboratory for the central Caribbean. The cooccurrence of clinoptilolite and phillipsite at Sites 150 and 154 doubles the number of reported cooccurrences of these minerals from the Deep Sea Drilling Project. At Site 150 the phillipsite crystals were distinctly larger than those of clinoptilolite. At Site 154 minor clinoptilolite was found by the $\mathrm{x}$-ray mineralogy laboratory; only phillipsite was detected optically in our laboratory. In the remainder of the central Caribbean samples, clinoptilolite was found commonly in Sites 146 (below the middle Eocene), 150 (early Eocene and Santonian), 151 (early Paleocene), 152 (late Cretaceous), 153 (Maestrichtian), and 148 (older sequence, age not known). It is either associated with other volcanic detritus or, more commonly, simply found in otherwise featureless clay samples. It is definitely associated with basaltic ash in Site 146 and could be in Sites 150 and 152. A further possible occurrence, which has not been confirmed by $\mathrm{x}$-ray, is as replacement of the centers of plagioclase fragments in a basaltic ash from Site 153. Minor amounts of clinoptilolite detected by x-ray diffraction (Fan et al., this volume) are more widespread.

Phillipsite is scarce in the central Caribbean late Tertiary, being prominent only in Samples $150-4$ and $153-1$. It was not found on the Aves Ridge. At Site 154 it is prominent and occurs both in the lower part of the upper pelagic sequence and in the lower turbidite sequence. The association of phillipsite with calc-alkaline volcanic crystal debris is unmistakable; none of the associations is with basalt. Phillipsite possibly occurs with glass at Site 154; in no case was zeolite seen forming from glass. Two older occurrences of phillipsite (Fan et al., this volume, Figure 3) are based solely on $\mathrm{x}$-ray diffraction results showing minor quantities.

Recognizable volcanic glass in the central Caribbean is confined to Sites 149,151 , and 152 and apparently represents pumice in all three sites (though some glass in Site 152 could conceivably be air-borne debris). It is commonly younger than the bulk of the zeolite with which it occurs, but in Site 149 phillipsite is found in a pelagic clay sequence much higher than the glass. At a time (Paleocene) when cristobalite and montmorillonite were evidently replacing volcanic glass in Site 146, glass was being preserved in very good condition in Site 152, which is more calcareous than is Site 146. Lime content, however, is not the only determining factor here; the siliceous clays of Site 146, which are evidently altered ashes, occur interbedded with chalks, none of which show glass. Some other chemical factor may be responsible for the difference in preservation, or the two original glass populations may have differed. Evidence for the latter is the abundance of plagioclase and hornblende at Site 152, and their virtual absence at Site 146. Possibly, the difference in preservation reflects differences in sedimentation rates, which may have governed the extent of ionic diffusion from the supernatant seawater.

\section{Garnet}

One of the most remarkable mineral occurrences in the Leg 15 sediments has been the garnet found in Sample 146-15-4 (10) (Plate 7, Figures 8, 9) and tentatively identified in Sample 153-4-3 (103) (Plate 7, Figures 11-13). In neither case are these minerals to be confused with the detrital garnets of continental origin found in turbidites, or as presumed turbiditic debris dispersed in clays (discussed below).

The garnet in Sample 146-15-4 (10) occurs as rectangular plates, showing some $45^{\circ}$ angled facets, and growthlines (Plate 7, Figure 8). The largest plates are about 50 microns long and 30 microns wide, but most of the grains do not exceed 20 microns in any dimension. The garnet is golden to brown in transmitted light. Examination 


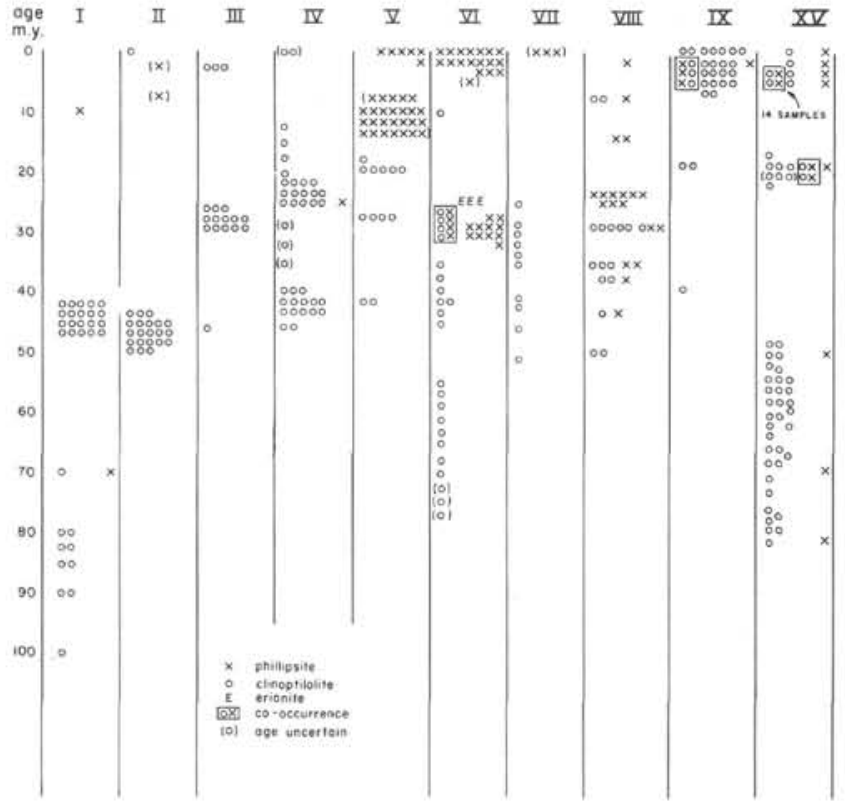

Figure 3. All occurrences of zeolite species recorded in $x$-ray results for Legs $1-4$ (Atlantic) and 5-9 (Pacific) of Deep Sea Drilling Project and for Leg 15. Plotted against time. Each symbol represents a core in which a zeolite occurs.

of a small sample of the marl near the smear slide yielded no crystals, and the only sample available to analytical work was a few small grains removed from the original smear slide. X-ray diffraction (small powder camera, $\mathrm{Cu}$ and Co radiation, of a single grain powdered between glass plates and mounted on a gelatin fiber) gave very good powder patterns. The unit cell dimension, determined by extrapolation methods from eleven strong back reflections, is $11.607 \pm .006 \mathrm{~A}$, which is, within observational limits, the value for spessartine. Because of the deep color of the garnet, it was tentatively concluded that it is very nearly this end member, though microprobe analysis will be necessary for confirmation. The flattened rectangular shape of the crystal fragments in the smear slide and the growth lines probably indicate that a skeletal crystal ("hopper" crystal) that had grown authigenically in the sediment was crushed during the making of the smear slide. The shape of the fragments and the color of this garnet set it completely aside from detrital garnets: it is most likely authigenic, and probably spessartine.

The occurrence of spessartine garnet, or of aluminous garnet rich in the spessartine end member, in lowest grade metamorphic rocks is well known. One occurrence of spessartine in a Franciscan chert (Bloxam, 1959) is especially noteworthy here; the present sample could indicate that spessartine may actually form during authigenesis rather than earliest metamorphism.

Tiny octahedral crystals, with dodecahedral modifications and possible cube faces, of sizes near the optical resolving limit of the microscope, were found in a smear slide from Sample 153-4-3 (103). No grains were found in nearby sediment samples, and the only samples examined were taken from the original smear slide. These crystals are uniformly small; only a few exceed 10 microns in their greatest dimension. They are brownish, have sharp crystal edges, have a high index, and, with a few exceptions, appear completely isotropic. A single uncrushed, unoriented grain was mounted in a small powder camera and photographed with $\mathrm{Cu}$ radiation. $\mathrm{A}$ few spots only were recorded; their spacing, intensity, and implied symmetry (the grain itself was quite dimensionally non-equant) appear compatible with isometric symmetry and with garnet. However, no further data are available. The powder pattern is appropriate neither for sphalerite nor spinel. We tentatively conclude that the mineral is a garnet. The size of the crystals, their association, and their form preclude transport in a turbidite. However, the possibility arises that they could be volcanic and not authigenic. Iron and iron-manganese garnets are found in siliceous volcanic rocks from a variety of occurrences. The age of the sample (middle Miocene) corresponds to one of the major siliceous igneous events of Central America, the eruptions resulting in vast ignimbrite sheets in Guatemala, Honduras, and Nicaragua (Williams and McBirney, 1969). Although garnet has not been specifically reported by these authors, the small size of these grains would make their detection in a thin section of ignimbritic rock quite improbable. The identification of these crystals as garnet is likely and the further possibility that they represent the remains of pumiceous volcanic debris should be considered.

\section{Barite}

Barite is a common mineral in both thin sections and in smear slides of older samples (Plate 4, Figures 1-4; Plate 7, Figure 7). It is euhedral to subhedral and in smear slides appears to be flattened on 001 . It is easily distinguished from the drilling-mud which is quite anhedral.

An especially handsome crystal form is exhibited by barite crystal aggregates washed from pelagic clay from Sample 150-3 (CC) (Plate 1, Figures 1 and 2). These barite "fans" are very delicate and, when fully developed, approximate double-ended, feathery "dumbbells."

The occurrence of barite in limestone is consistent with a biological origin for this mineral. However, the association of barite with sub-alkalic volcanic detritus, especially with detritus from the quartz-alkali feldspar-biotite sub-alkalic association of the late Cretaceous (Chapter 22), suggests a volcanic source for the barium. Several sediments were analyzed for barium (Table 1). The values of this element are higher in volcanic sediments than in non-volcanic sediments (compare analyses 150-5-1 and 150-5, CC with $150-2-1,150-3-1$ and $150-4-1$; and 153-16-2, 153-17-1, 146-10, CC; and 146-39R-2, 76-80, clay, with 146-27, CC, light, 146-27, CC, dark, 146-34-1, and 146-39R-2, 76-80, basaltic ash). Biological agencies are demonstrably important in some cases, however; the most spectacular is the occurrence of coarse barite crystals in a burrow (Plate 4, Figure 1), where a neighboring dark sediment band (analysis 146-34-1) has only 750 ppm of the element.

\section{Gypsums}

Gypsum is not a common mineral in Leg 15 sediments. Of the five occurrences found in our laboratory, one was detected by x-ray only (Sample 152-18-2, 62; Maestrichtian 
chalk) and its significance is not understood. In 146-34-1 (103) (Santonian) a single large grain was found in a smear slide of a limestone. This grain was a large rounded subhedron, apparently with a sectorial growth pattern and abundant inclusions. Large, rounded grains occur in Sample 153-2 (CC), in a washed sample along with volcanic quartz, foraminifera and Radiolaria replaced by pyrite, and with manganese micronodules. The bulk of the fine-grained part of the sample consists of quartz grains, evidently of turbidite origin. In Sample 153-4-3 (96-97) a single large grain, similar to those in the Site 146, Core 34 and Site 153 , Core 2 occurrences, was found in a clay. All of these grains appear to be flattened on 110 , but the rounded nature of the grains and their abundant inclusions makes this determination very tentative. In Sample 154-4-3 (13-14.5) very ragged gypsum crystals were found in a turbidite.

In all but the Site 146, Core 34 and Site 152, Core 18 occurrences (the latter not studied optically) gypsum cooccurred with pyrite. The anhedral, rounded (dissolved) appearance of the gypsum and the sharpness of the pyrite crystals, as well as the association of gypsum with patently transported detritus in at least two occurrences, leads to the conclusion that these crystals were derived from a near-shore environment by turbidity currents. The Site 146 , Core 34 occurrence is in a section which has abundant intercalated radiolarian turbidites, which allow an analogous origin to be suggested here (except that the gypsum might have originated in an intrabasinal, not a near-shore environment.).

Gypsum was also detected by $\mathrm{x}$-ray diffraction at Site 147 cooccurring with dolomite and pyrite (Fan et al., this volume).

\section{Fish and Worm Debris}

Fish and worm debris, mainly bones and plates, occur widely in the Leg 15 sediments. It is especially abundant in the more organic, reduced sediments, but fish bones and teeth are also widespread in linestones and chalks.

Fish debris is colorless or pale amber to deeply colored red brown. The oldest samples are the most deeply colored; possibly a metamorphic effect forming dispersed reduced carbon is responsible. Recognizable bones, some nearly articulated, were found in many of the older limestones. Plate 2 shows some of the better examples, and Plate 3 shows debris in smear slides.

The recognition of fish debris is not always straightforward. Mica flakes, especially biotite, commonly have a very similar appearance. Most fish bone fragments, however, are oriented with the apatite fibers parallel to the slide. A few have these fibers oriented normal to the plate, and these give a negative, uniaxial figure, as does biotite.

Worm debris has been more difficult to recognize. Occasionally a fragment of a worm jaw with some structure can be recognized. The color of this material is generally very dark brown. It is not at all certain that some of the material called fish or worm debris might not in reality be from an arthropod.

Some of the Cretaceous samples which occur in the section with recognizable basaltic ash (as in Sites 150 and 151) contain glauconitized scaly plates which might be fish debris. No structures which might have confirmed this identification were noted, however.

\section{Plant Debris}

Spores recognizable largely as spherical and rather featureless, commonly collapsed bodies are found in the more reduced organic sediments, especially at Sites 147 and 154 , but also including the lower part of Site 146. Pollen was not definitely recognized in smear slides but probably can be found in suitable preparations of this same material.

Wood debris was found in turbidites from Site 154. Its shredded appearance, deep red brown color, and high relief make it easily recognizable.

\section{Iron-Manganese Nodules and Micronodules}

The recognition of manganese nodules as buried is difficult. Piston coring in areas of known manganese nodules generally yield few subsurface nodules, and it has been concluded that genuinely buried nodules might be very rare. On Leg 6 of the Deep Sea Drilling Project, nodules were recorded in the upper 15 meters of pelagic clays (Pimm et al., 1971, p. 1137). At Site 150 of Leg 15 several nodules were found in Cores 4 and 5 at subbottom depths of about 100 to 115 meters. It is not certain from the occurrence whether these nodules were a)buried, having grown elsewhere, or b) were found in their present position as a result of drilling disturbance. The depth of the occurrence appears to preclude the last possibility. The problem was further complicated by the discovery of micronodules in a washed sample in the same core $(150 / 5)$ as the large nodules. About a milligram of picked micronodules (as well as a similar sized sample picked from the apparently turbiditic assemblage of Sample 153-2, CC) was analyzed for $\mathrm{Fe}, \mathrm{Mn}, \mathrm{Ba}, \mathrm{Sr}$, and $\mathrm{Cu}$. Two larger nodules were analyzed for these and other major elements (Table 1 , analyses $150-5-4,100 ; 150-5-4,42-43 ; 153-2, \mathrm{CC}$; 150-5-3, 76-77). The larger nodules are distinctly iron-rich. This would imply rapid growth, but does not settle the question as to whether the nodules grew in situ, were transported in by natural means, or were emplaced by a drilling disturbance.

The micronodules, however, are very hign in $\mathrm{Mn}, \mathrm{Ba}, \mathrm{Sr}$, and $\mathrm{Cu}$. (The analyses must be regarded as approximate because of the small sample size, but ratios are significant.) The micronodules very probably were all transported in turbidites; the association with other transported minerals in the 153-2 (CC) sample is unmistakable, and Core 4 from Site 150 shows both easily recognized and covert terrigenous debris (see below). The large iron-rich nodules remain problematical, but their occurrence with manganese-rich micronodules is noteworthy. The occurrence of demonstrably transported turbiditic debris in this part of the section, however, casts some doubt on their origin in situ. The cooccurrence of oxide nodules with widely differing FE:Mn ratios attests to the persistence of unstable minerals in deep-sea sediments.

\section{Ferruginous Clay of Site 148}

The unconformity between a Miocene and younger pelagic sequence and older (but not exactly dated, owing to reworked nature of the fossils) volcanic sandstones at Site 
148 is marked by a chocolate-colored, clay-like substance. This material also is found in the underlying sandstones, where it occurs as a cement. Samples were x-rayed, showing only peaks for quartz and calcite (both probably tramp minerals) and poor peaks of goethite at $4.18 \mathrm{~A}$ and $2.45 \mathrm{~A}$. Attempts to prepare samples by sedimentation and by careful packing did not improve the x-ray patterns.

The chemical composition (analysis 148-27, CC of Table 1) shows, besides the expected high iron content, a low manganese content, only minor barium, strontium, and copper, and surprisingly high phosphorus. The values of these latter elements immediately set this iron-rich clay apart from the clays associated with submarine basalts. The phosphorus is especially perplexing; the calcium content of the clay is far too low for all of the phosphorus to occur in apatite. Either an iron phosphate mineral (not detected by $\mathrm{x}$-ray) occurs, or phosphorus may occupy a lattice position within goethite. According to the data of James (1966), fully 5 percent of the more than 100 analyses of iron-rich sedimentary rocks in that compendium show excess phosphorus. The only modern iron-rich sediment with such high phosphorus is bog iron ore (range in $\mathrm{P}_{2} \mathrm{O}_{5}$ for Finnish lake ores $0.45-1.25$ percent), but these same ores are high in manganese. The Site 148 sample, thus, is unusual in its high phosphorus and low manganese contents. One explanation is that it might not be marine at all, but the remnant of the subaerial or shallow marine weathered crust formed on these volcanic sandstones. Marlowe (1971) reports ferruginous clays from dredged samples from sea mounts of the Aves Ridge. Some of these were phosphatic, but several were calcareous or manganiferous, or both. The similarity between some of Marlowe's samples and the Site 148 clay strengthens an argument for a submarine origin.

\section{Chert at Uuconformity Between Cretaceous and Tertiary}

At Site 151 a thin layer of chert was found beneath the Paleocene chalk section and above a highly disturbed, aut apparently lithologically heterogeneous mixture of radiolarian and foraminiferal turbiditic sandstones, green micaceous clays, organic clays, and limestones. This chert in hand specimen is a layer about $10 \mathrm{~cm}$ thick and is more or less gerruginous with a brecciated appearance. Two samples which were found in lower cores evidently as chips borken from this layer, were analyzed and one was thin sectioned. Analyses 151-12-1 and 151-13-1 (Table 1) give little information about the origin. Besides silica, only iron shows an appreciable content. The remaining element contents are simply scaled down from some more normal original values; phosphorus is low and the potassium/sodium ratios high In thin section (Site report 151) abundant silicified foraminifera and irregular, gerruginous structures that could represent silicified fish debris are seen. Evidently this chert represents typical "hard ground" reflecting a period of nondeposition, possibly following block faulting at the end of the Cretaceous.

\section{Turbidites of Continental Origin in the Central Caribbean}

Miocene and Pliocene (and one doubtful case from the Pleistocene) sediments from the Venezeulan Basin contain turbidites of continental origin (Figure 4). Only Samples 150-4-1 (90) and 31-7-1 (121-132) (from Leg 4) were distinguishable as sandy layers in the cores themselves; the remainder were found during smear slide or other mineralogical analyses. The dominant feature of all except two of these occurrences (250-4, CC, a single garnet grain in a washed sample; and 149-5-3, 50, an occurrence of a few mineral grains in a smear slide) is the abundance of equant, irregular grains of quartz with subordinate feldspar of plutonic aspect.

Other minerals found are as follows:

Sample 150-4-1 (90) (early Miocene) - conspicuous green hornblende, ?alkali hornblende (high absorption), zircon (pink to brownish, rounded, zoned, apparently metamict), garnet (colorless to pinkish, rounded), apatite (rounded), rutile (rounded - one geniculate twin seen), tourmaline (very round - pinkish to green olive) and zoisite-epidote. Also found were rounded plates of kyanite, a single grain of glaucophane, another grain of amphibole whose absorption colors are typical for glaucophane or barroisite, and a single irregular grain of inky-blue corundum (sapphire), showing some marginal colorchange to brown.

Sample 250-4-(CC) (early Miocene) - a single pink garnet grain in a washed and sieved paleontological sample.

Sample 15-5-3, 78 (early Miocene) - green hornblende, rutile, zircon, toumaline, biotite.

Sample 151-1-1 (140) (early Pliocene) - green hornblende, brown hornblende, muscovite.

Sample 153-2 (CC) (late Miocene) - brown biotite, green hornblende, apatite, zoisite-epidote. This sample also contains volcanic quartz, rounded gypsum crystals, and manganese-rich micronodules.

Sample 31-7-1 (131-132) (early Pliocene) - zircon (rounded, zoned, metamict), green hornblende, apatite, zoisite-epidote, garnet (colorless to pink) and tourmaline (pink to green olive).

Sample 149-5-3 (50) (mid-Pleistocene) - this sample contains a suspiciously abundant and varied foraminiferal assemblage (as seen in smear slide). It could be partially turbiditic.

A part of this mineral assemblage (especially in Sample $153-2$, CC) could well be volcanic in origin, but the bulk is derived from two discrete types of metamorphic terrane: high-grade continental basement (tourmaline, zircon, rutile, corundum) and blue-schist metamorphics (glaucophane, kyanite, possibly blue green amphibole). These two rock types coexist around the Venezuelan Basin only in northern Venezuela, and the turbidites must be derived from this area.

Figure 5 is an air-gun tracing across Site 150, showing the presence of a tilted, narrow abyssal plain just north of the continental rise of South America. A turbidity current descending the continental rise would have to climb the north side about 500 meters to reach Site 150 . This abyssal plain might be a moderately effective sediment trap. Figure 5 shows this plain at one longitude; other crossings of this feature show that it persists along the entire Venezuelan-Dutch Antillean continental rise and extends westward to the eastern Colombian continental rise.

The proximity to South America would predict far more turbidites than are actually found. Apparently the relatively minor abyssal plain has served to trap terrigenous sediments 
$146 / 149 \quad 150 \quad 151$

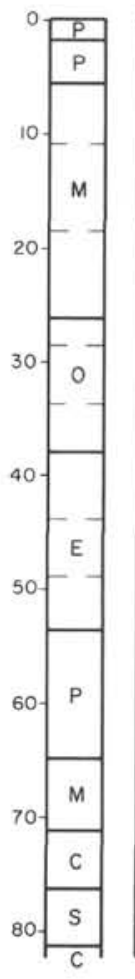

Cu Copper

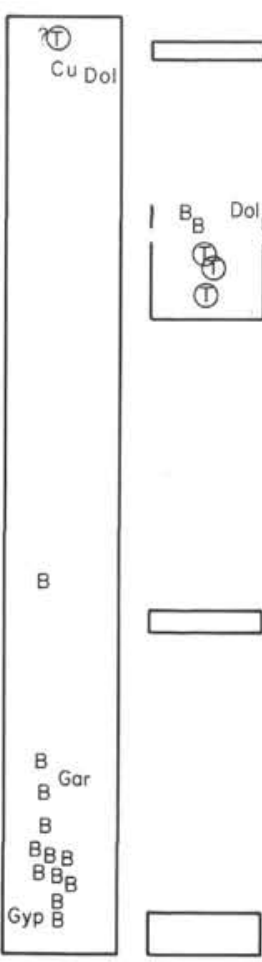

$\begin{array}{ll}\text { B Barite } & \text { Dol Dolomite } \\ \text { Gyp Gypsurn } & \text { Gar Garnet }\end{array}$

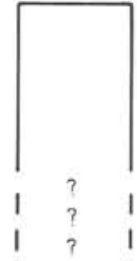

$1 ?$

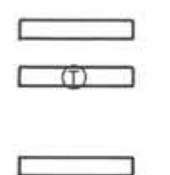

SITE 31
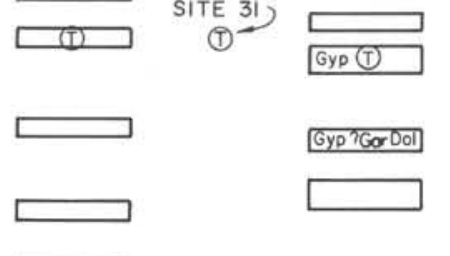

152
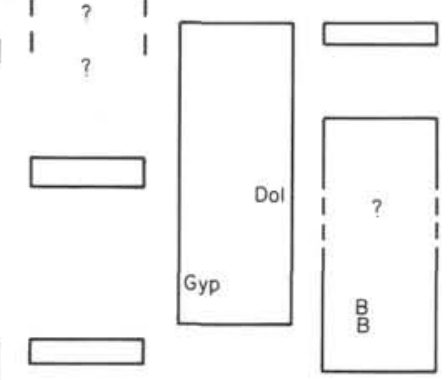

(1) Turbidite of continentol origin
Figure 4. Cores with occurrences of miscellaneous authigenic minerals and turbidites of continental origin in the central Caribbean, including Site 31, Leg 4. Time scale as for Figure 2.

through much of the late Cretaceous and all of the Tertiary, becoming a less effective trap only during a brief MiocenePliocene interval. The tilting of the floor of this narrow abyssal plain (seen also in Figure 5 of Donnelly, Magnetic Anomalies..., this volume) and the inclination of both bottom and subbottom reflectors suggest that this abyssal plain might be the expression of a dynamic process - a somewhat subdued oceanic trench indicating minor subduction. The transition from calcareous to clay sediment in the Tertiary between Sites 149 and 150 (with Site 29, Leg 4, intermediate in depth and sediment character) suggests that the depth difference may be of long duration, and the process of minor subduction might have been operative over most of the post-Cretaceous. The slight relaxation implied in the Miocene-Pliocene interval could correspond with the cessation of Lesser Antillean pumice-producing volcanism of the late Eocene through early Miocene. Both events could have resulted from a reduction in relative plate movements which in this area might have persisted until the late Pliocene, at which time volcanic activity was renewed.

\section{Green Clays and Basaltic Ashes}

The distinctively green or dark brown clays and basaltic ash beds seen clearly in Sites 146 and 153 and much less clearly in Sites 150, 151, and 152 are of interest for several reasons. Their identification as dominantly of basaltic-ash origin shows that the basaltic episode of the late Cretaceous lasted several million years. Their unusual mineralogy and lithology are a consequence both of unusual conditions of deposition and of marked diagenetic changes.

Lithologically these beds range from nearly pure basalt ash (whose mineralogy and texture is discussed and illustrated in separate chapters of this volume) to a waxy, bright green, hard clay. In Sample 146/39R these lithologies alternate in a spectacular fashion, with the ash beds somewhat graded and apparently eroding the clays to a limited extent. Burrowing, however, has evidently destroyed some of the original textural character of the sediment.

The coarse ash beds (Table 1, analysis 146/39R-2, 76-80, basaltic ash) have chemical compositions very nearly identical to those of unaltered basalt, differing principally in having somewhat higher potassium. The green clays associated with this ash consist dominantly of mica (x-ray diffraction). Chemically (Table 1, analysis 146/39R-2, $76-80$, green clay) they are very similar to the ash, but have distinctly higher potassium and barium. Evidently these clays are nothing more than the very fine basaltic debris which settles after the coarser materials. The eruptions themselves could hardly have been explosive at the high water pressures of these depths, very likely the pyroclastics resulted largely from chilling phenomena when the hot magma encountered cold water.

Analyses of three other greenish or dark, apparently basaltic clays (from Sites 151 and 153) are given in Table 1 (analyses 151-13-2, 153-17-1, 153-18-3). These are similar to the Site 146 clay, except that one example has much higher potassium. One of these clays (Sample 153-18-3) has abundant authigenic K-feldspar, and the association of basaltic clay with this mineral will probably be found to be more widespread.

Another limy clay from Site 153 (Sample 153-16-2) is similar, but apparently has a higher content of organic matter and more bound water. The phosphorus value for this clay reflects the occurrence of fish debris in this sediment (see Plate 2, Figures 3, 5, and 6 of nearby sediments). Barite crystals are also found scattered in this material. The Site 153 clays seem to represent deposits of basaltic ash in highly reducing environments. Possibly the chemical reaction between the ash and seawater was partially responsible for the lowered Eh.

The tendency of basaltic ash to absorb potassium, forming green mica (possibly glauconite, but whose precise properties remain to be studied) and authigenic K-feldspar is remarkable. The high chemical potentials for potassium are evidently the result of the presence on the sea bottom of very fine-grained (hence, large surface area), chemically reactive glass, from which mica and K-feldspar could nucleate and grow very readily.

\section{CHEMISTRY OF SITE 150}

Six analyses of pelagic and zeolitic clay are given in Table 1 (analyses 150-2-1 through 150A-2, CC) and plotted in Figure 6. X-ray diffraction traces of the five upper samples are shown in Figure 7. This sequence represents a transition from a zeolitic clay, with some carbonates, 


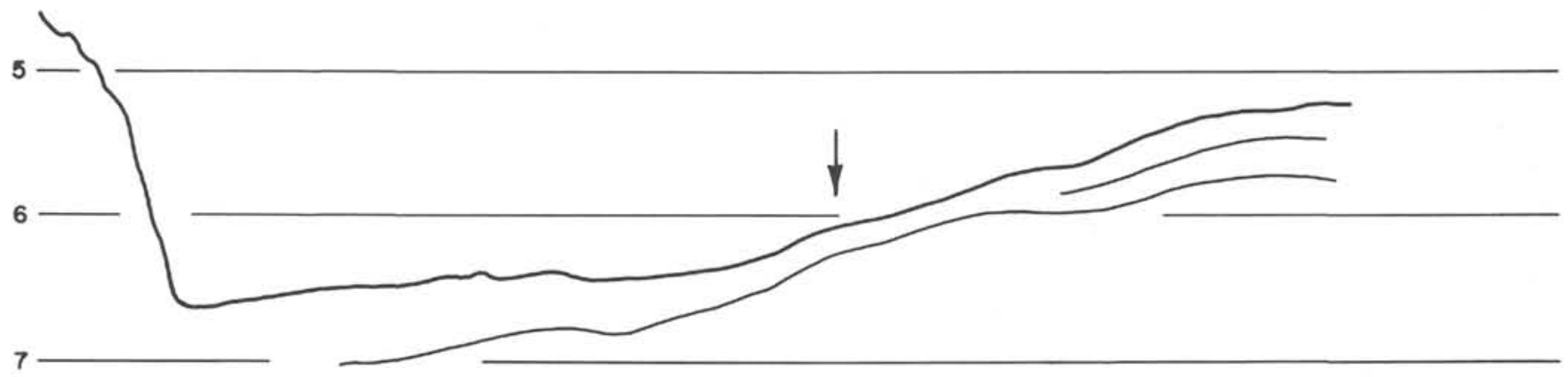

S

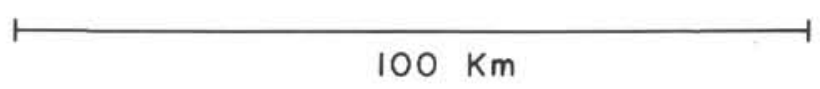

$\mathrm{N}$

Figure 5. Tracing of air-gun profile across Site 150, showing seconds of reflection time, bottom profile, and two sub-bottom reflectors.

upward into a pelagic clay. This transition is apparently dominantly the result of decreased vulcanism; the abundance of feldspar phenocrysts in core catcher samples washed for paleontological analysis decreases markedly from Samples 150-5(CC) (abundant) through 150-4(CC) (common) to Sample 150-3(CC) (scarce). The x-ray diffraction traces of Figure 7 reflect this same trend: clinoptilolite and phillipsite are prominent in the lower two samples (with phillipsite relatively more prominent upward) and sepiolite appears in the lowest sample.

Chemically, the transition is most marked by an upward abrupt increase of $\mathrm{Al}_{2} \mathrm{O}_{3}$ (Figure 6) at around 100 meters depth. Potassium, titanium, and iron show a similar trend, although potassium is higher again in lower samples. None of the minor elements can be shown to reflect the onset of volcanic activity; calcium, strontium, barium, phosphorus, and copper may be controlled biologically, and magnesium and sodium by silicate-interstitial fluid equilibria.

Analyses 150-5-1 and 150-5(CC) of Table 1 are of the two zeolite clays, one of which has sepiolite. An inspection of the values for the various elements shows that the composition bears a remarkable resemblance to that of a calc-alkaline andesitic ash, except that potassium is slightly high. Very likely the interesting mineralogical assemblages of these two samples do not imply any sort of metasomatic activity, but reflect instead nearly iso-chemical (except for potassium) alteration of volcanic ash in seawater.

\section{CHEMICAL HISTORY OF SEDIMENTATION AT SITE 146/149}

Continuous coring of 762 meters of sediments at Site $146 / 149$, with at least some recovery in all but two cores, has provided us with an almost unparalleled opportunity of studying 80 m.y. of pelagic sedimentation in the Caribbean. Chemical analysis of 75 samples from this core (Table 1) have been recast in terms of rate of supply of individual chemical species to the sea floor (Figures 8, 9, 10). The basic purpose of this approach is to attempt to determine the extent to which the total sedimentation might be broken into components: biogenic (calcareous, siliceous, phosphatic), terrigenous, volcanic, and diagenetic. Although little hope was held for a complete understanding of the importance of all of these agencies, we feel that this form of analysis has been very useful. The basic procedure is as follows.

The samples were air dried but not washed; thus the analysis includes both original solids and solute ions from the pore water. Of the latter, sodium has been corrected for that portion of the core shallower than 400 meters, based on the nearly constant $\mathrm{Na}$ content of pore waters to that stratigraphic level at nearby Site 29. The corrections for the other solute ions was felt to be negligible. The chemical sedimentation rate is

$$
\begin{aligned}
& \text { oxide percent } \times \text { sedimentation rate }(\mathrm{m} / \mathrm{my}) \\
& \times \text { density }(\mathrm{g} / \mathrm{cc}) \times 1000 \\
\mathrm{~m}= & \text { oxide sedimentation rate }\left(\mathrm{g} / \mathrm{cm}^{2} 100,000 \mathrm{y}\right) .
\end{aligned}
$$

As has been discussed more completely elsewhere (Site Report 146/149) the sedimentary sequence is divided into two major units. The lower lime-rich unit has variable, and locally, high silica, limited terrigenous debris, abundant authigenic minerals, and distinct volcanic ash beds. The younger unit has little silica, abundant terrigenous minerals, dispersed volcanic ash, and was apparently deposited in an environment in which the lysocline position fluctuated widely.

Of all the chemical species, calcium $(\mathrm{CaO}$, Figure $8 \mathrm{c})$ is the most clearly assignable to a single category of origin: it is virtually all biogenic. Only very limited $\mathrm{CaO}$ is brought down in silicates (mainly plagioclase), as seen in the very 

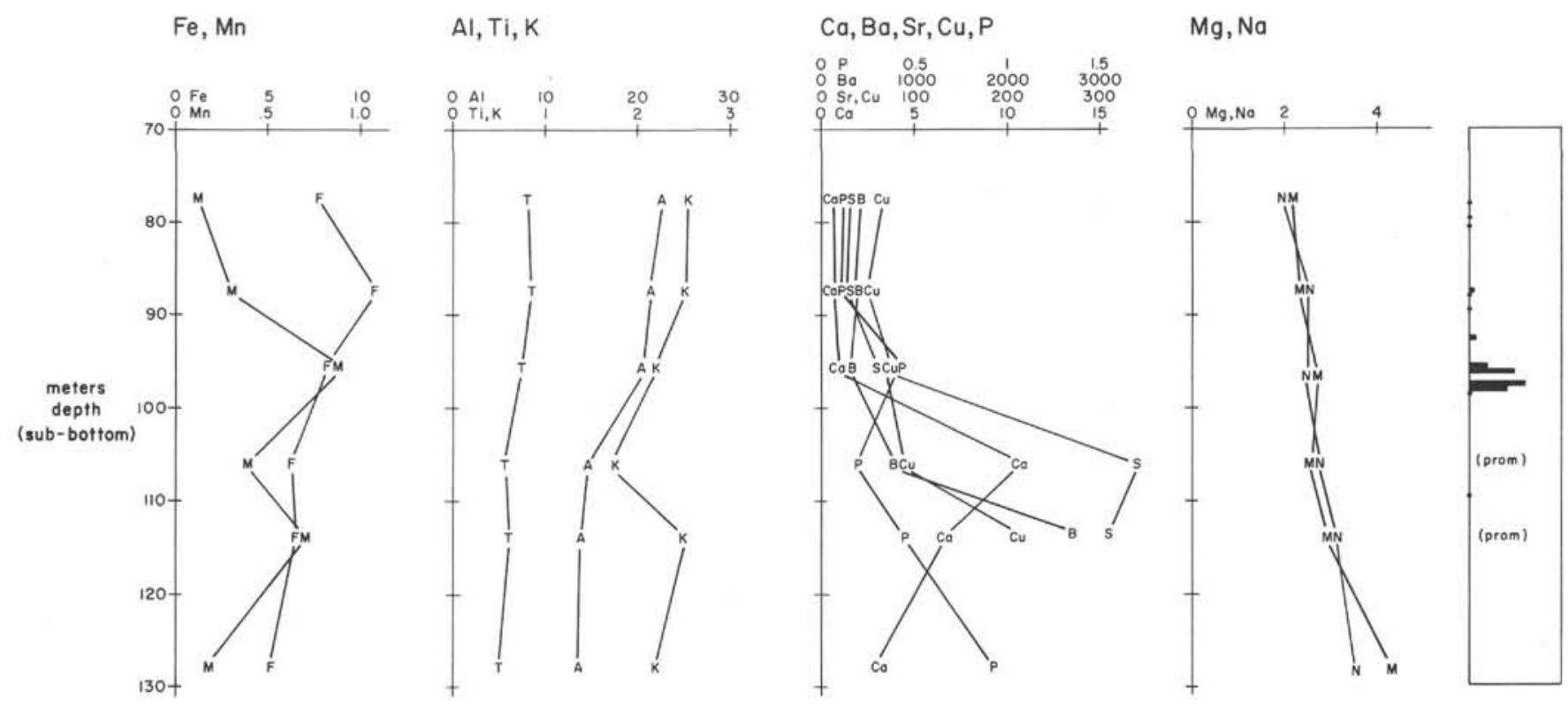

Figure 6. Abundances vs. depth of chemical species at Site 150/150A. Samples are air-dried but not washed. Note that symbols are not necessarily the standard symbols for the chemical elements, and that $\mathrm{Fe}, \mathrm{Mn}, \mathrm{Al}, \mathrm{Ti}, \mathrm{K}, \mathrm{Ca}, \mathrm{P}, \mathrm{Mg}$, and $\mathrm{Na}$ are abundances as oxide percentages. $\mathrm{Ba}$, $\mathrm{Sr}$, and $\mathrm{Ca}$ are in ppm. The histograms on the right record $\mathrm{CaCO}_{3}$ percentages. (Prom) means carbonates prominent in smear slides.

low rates of Ca supply to the sea floor in the upper clay unit (75-138m).

Silica $\left(\mathrm{SiO}_{2}\right.$, Figure $\left.8 \mathrm{~d}\right)$ is supplied both as siliceous organisms and as detrital silicate debris. Periods with high $\mathrm{SiO}_{2}$ supply and low $\mathrm{Al}_{2} \mathrm{O}_{3}$ supply (such as $300-400 \mathrm{~m}$ especially, and most of the interval below $400 \mathrm{~m}$ ) are obviously periods of dominantly biogenic supply of $\mathrm{SiO}_{2}$, unless detrital terrigenous quartz is present. Because quartz is known from the lower sequence only as the recrystallization product of opaline Radiolaria or as rare volcanic phenocrysts, we conclude that the entire lower interval is one of conspicuous supply of biogenic silica.

The problem of the formation of chert at Horizon $\mathrm{A}^{\prime \prime}$ is clarified by a further consideration of the trends of silica supply rates shown in Figure 8d. One current view is that chert represents high supply rates of silica to the sea floor. At Site 146 chert occurs from about 400 meters (Horizon $\left.\mathrm{A}^{\prime \prime}\right)$ to 575 meters. This interval actually corresponds to a relatively low rate of supply of silica to the sea floor. This trend suggests that the cherts of Horizon $\mathrm{A}^{\prime \prime}$ should not be considered as evidence for high rates of supply of silica, but must have another explanation. The lack of correspondence between lithification and silica contents in this interval has been noted above.

Phosphorus $\left(\mathrm{P}_{2} \mathrm{O}_{5}\right.$, Figure $\left.8 \mathrm{~b}\right)$ is another component which is distinctly biogenic. The generally high rates of supply in the lower unit are reflected in the abundant fish debris noted in that interval (Site Report 146/149). The chemical trends, however, show a gradual decline in phosphorus upwards to 400 meters which is not evident from smear slide studies. This decline, which must reflect the increasing tendency with time for fish debris to be recycled to the upper water, apparently reflects a gradual change in bottom water chemistry, which could of course be either a local or regional effect. Interestingly, although apatite crystals of volcanic origin are widespread (Site Report 146/149 and Donnelly and Nalli, this volume), the supply of phosphorus to the sea floor is not high at these levels (x symbols, Figure $8 \mathrm{~b}$ ). The rather high rate of supply of phosphate to the sea floor from 300 to 400 meters corresponds to the richly radiolarian interval of this site. Recognizable fish debris is not abundant in this interval, and the phosphorus might be concentrated in dispersed, fine-grained phosphorite.

The behavior of manganese $(\mathrm{MnO}$, Figure $8 \mathrm{a})$ is one of the most difficult to understand through this type of analysis. The supply of manganese is fairly uniform throughout the section. It is distinctly lower in the volcanic units of the lower sequence ( $x$ symbols) suggesting that manganese is basically an element that accumulates at a slow, constant rate and tends to be diluted by a sudden pulse of detritus. Manganese supply rates are slightly higher just below 500 meters, where supposedly manganese garnet has been found (see above) and where rhodochrosite has been detected by $\mathrm{x}$-ray diffraction (Fan et al., this volume).

The behavior of aluminum $\left(\mathrm{Al}_{2} \mathrm{O}_{3}\right.$, Figure $\left.9 \mathrm{~b}\right)$ reflects both terrigenous and volcanic supply. A number of volcanic beds ( $\mathrm{x}$ symbols) of the lower sequence show high supply rates for this element. Aluminum is one of the elements that does not "see" the high sedimentation rates of the 300 to 400 meter radiolarian interval, instead showing a nearly constant supply rate through this and the earlier, lowsedimentation rate interval from 500 to 400 meters. The decrease in the supply rate at 300 meters is marked for several non-biogenic elements, but perhaps mostly for aluminum. Also, the gradual increase from 300 meters to 


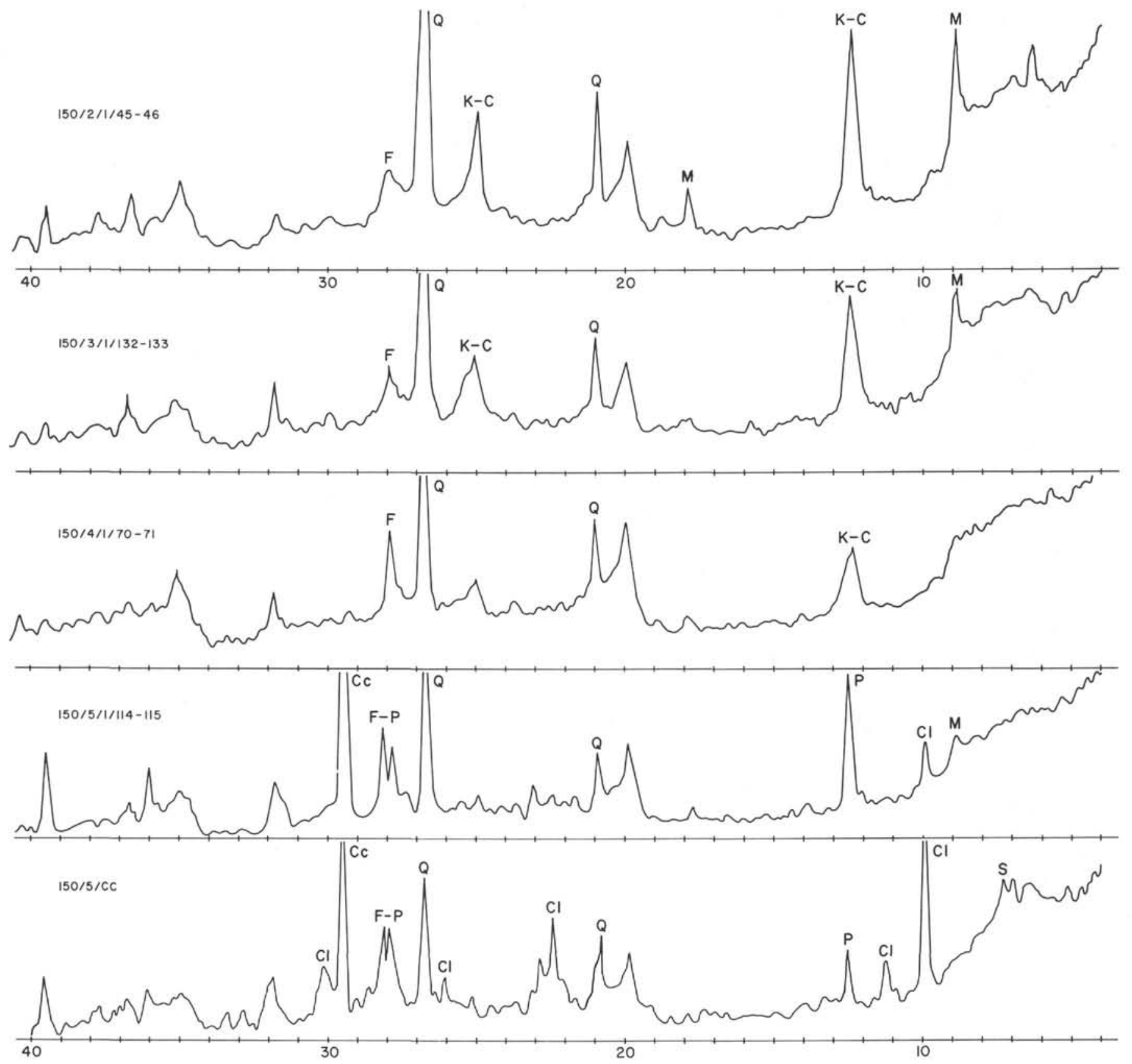

Figure 7. X-ray diffraction traces of the five upper samples of Figure 6 (Cu radiation). Scale is degrees $2 \theta . F=$ feldspar, $Q=$ quartz, $K-C=$ kaolin-chlorite, $m=$ mica, $P=$ phillipsite, $C l=$ clinoptilolite, $S=$ sepiolite.

the surface reflects perhaps more clearly than for any other element the gradual increase in the terrigenous and volcanic fractions above 300 meters.

Iron $\left(\mathrm{Fe}_{2} \mathrm{O}_{3}\right.$, Figure 9a) trends are largely parallel to those of aluminum. Several markedly high values near the base of the core reflect the formation of authigenic green mica (glauconite or celadonite) in the lower basaltic-ash clays.

Titanium $\left(\mathrm{TiO}_{2}\right.$, Figure $\left.9 \mathrm{~d}\right)$ follows iron and aluminum closely in the older sequence but less so in the younger. The concentration of titanium in volcanic ash units ( $\mathrm{x}$ symbols) in the lower sequence is especially marked and might reflect the sub-alkalic, rather than typically calc-alkalic, nature of these beds (Donnelly and Nalli, this volume).

The behavior of magnesium ( $\mathrm{MgO}$, Figure 9c) is very similar to that of iron, aluminum, and titanium. It is enriched in the lower unit volcanic beds ( $x$ symbols, Figure $9 \mathrm{c}$ ), does not reflect the 300 to 400 meter high overall sedimentation rate, decreases at 300 meters and gradually increases to the surface.

The ratio of aluminum to magnesium $\left(\mathrm{Al}_{2} \mathrm{O}_{3} / \mathrm{MgO}\right.$, Figure $10 \mathrm{c}$ ) was investigated in order to attempt to separate the volcanic and terrigenous components of silicate mineral supply to the sea floor. In terrigenous clay assemblages 
a)

$$
\frac{\mathrm{MnO}}{\mathrm{g} / \mathrm{cm}^{2} \cdot 10^{5} \mathrm{y}}
$$

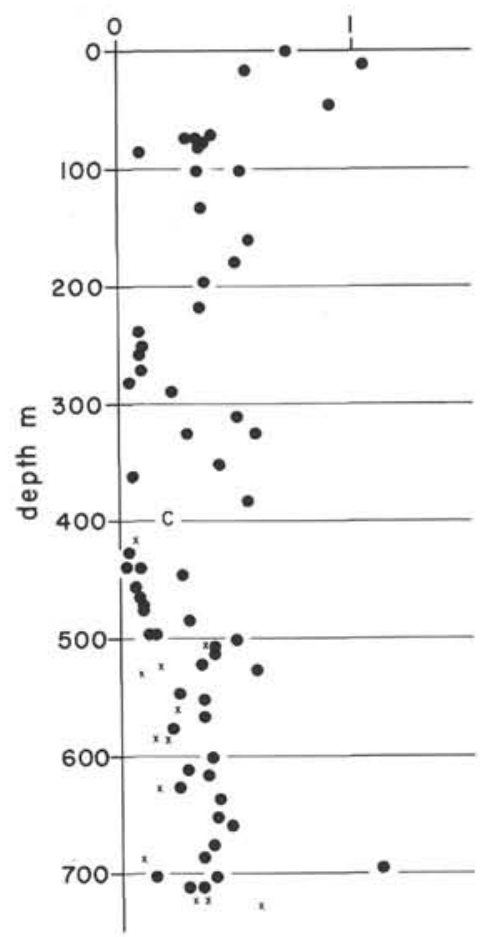

c)

$$
\mathrm{CaO}
$$

$$
\mathrm{g} / \mathrm{cm}^{2} \cdot 10^{5} \mathrm{y}
$$

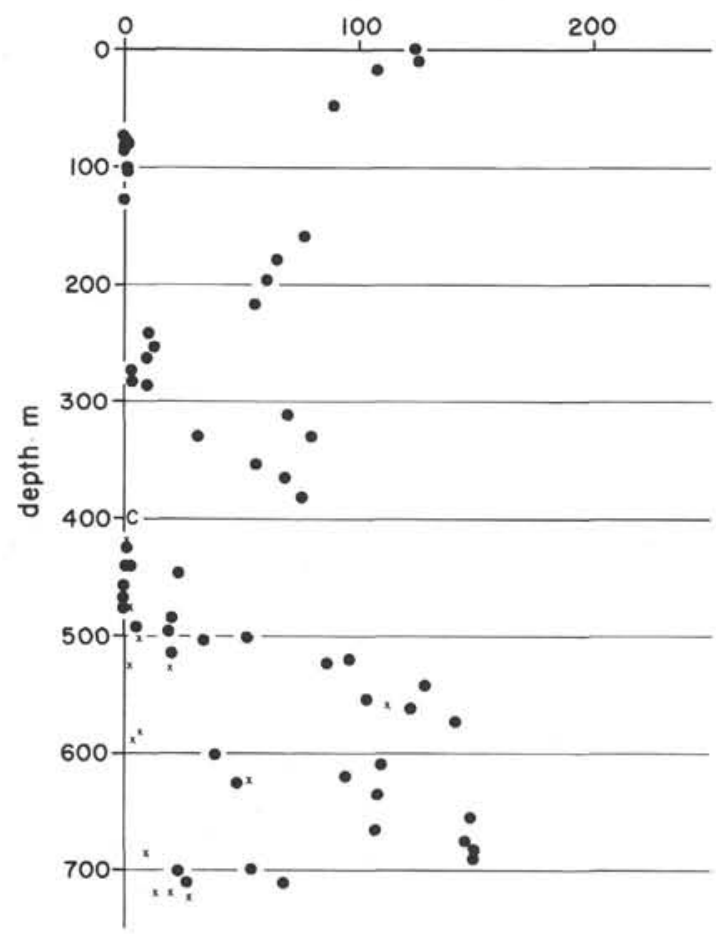

b) $\mathrm{P}_{2} \mathrm{O}_{5}$

$\mathrm{g} / \mathrm{cm}^{2} \cdot 10^{5} \mathrm{y}$

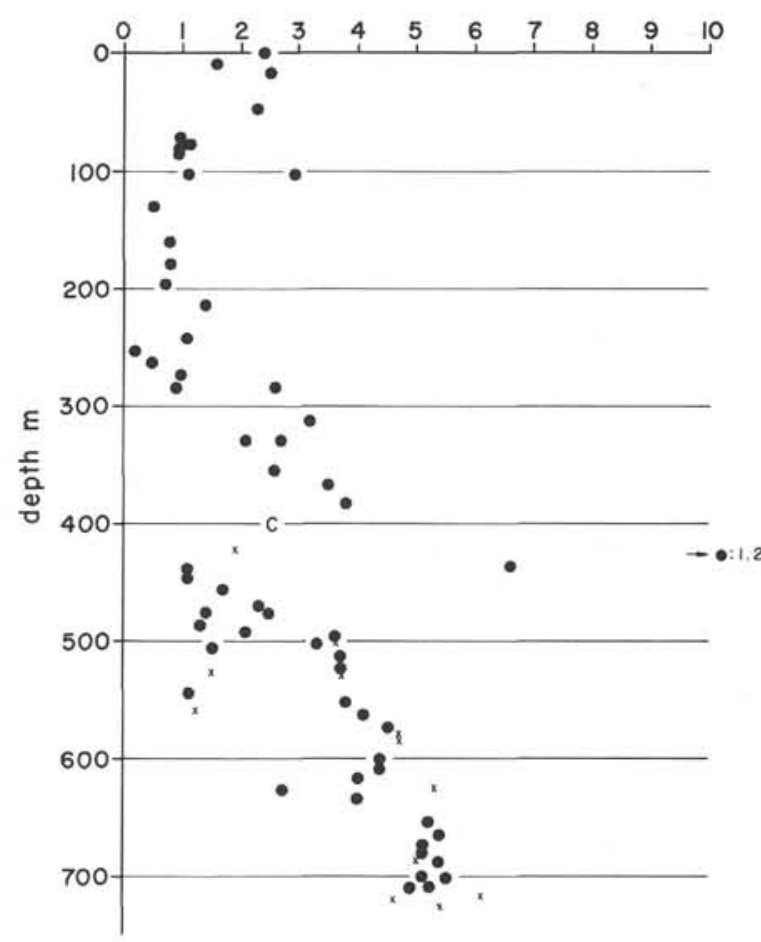

d)

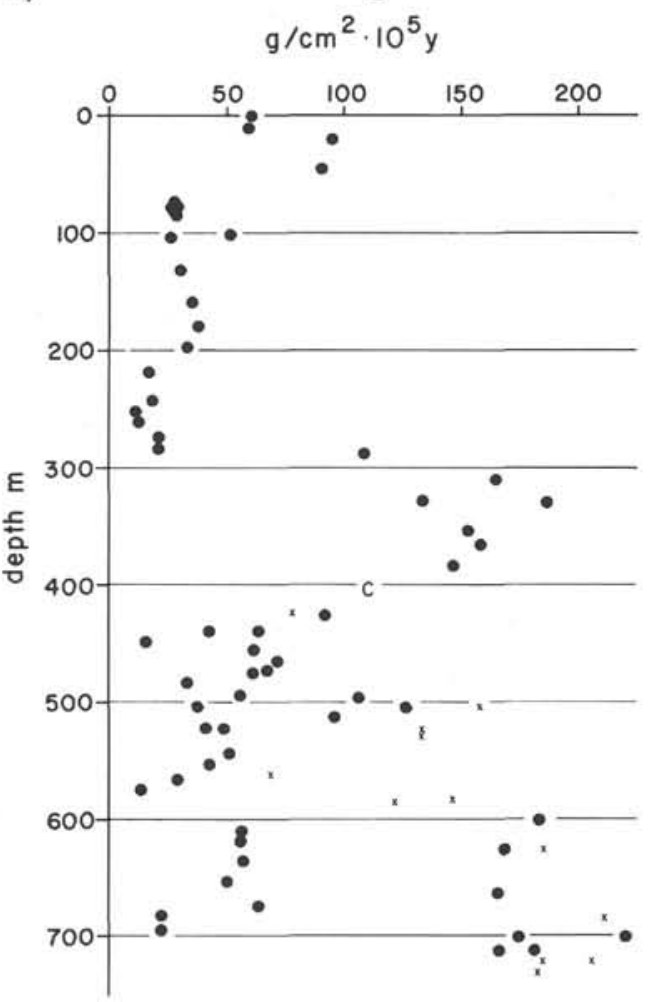

Figure 8. Plots of depth vs. rate of supply of chemical species to the sea floor. a) $\left.\mathrm{MnO}, b / \mathrm{P}_{2} \mathrm{O}_{5}, \mathrm{c}\right) \mathrm{CaO}_{\text {, d) } \mathrm{SiO}}$. Chert shown by $C$. Volcanic ash beds shown by $x$ symbols. 
MINERALOGY AND CHEMISTRY OF CARIBBEAN SEDIMENTS

a)

$$
\begin{gathered}
\mathrm{Fe}_{2} \mathrm{O}_{3} \\
\mathrm{~g} / \mathrm{cm}^{2} \cdot 10^{5} \mathrm{y}
\end{gathered}
$$

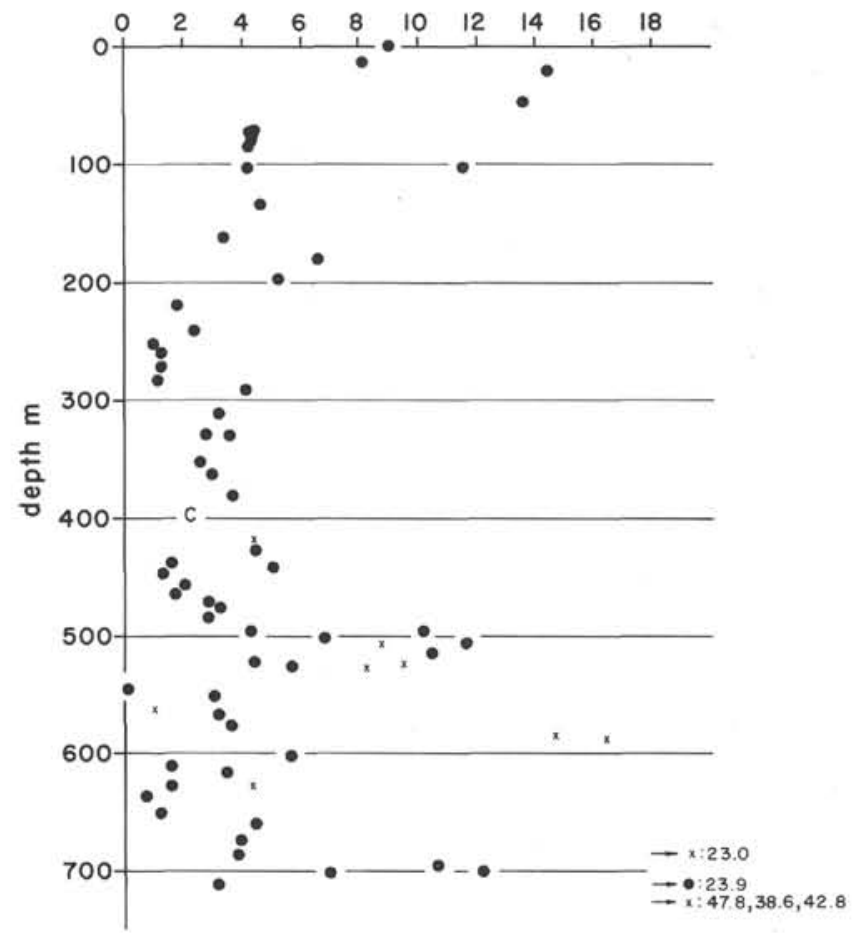

c)

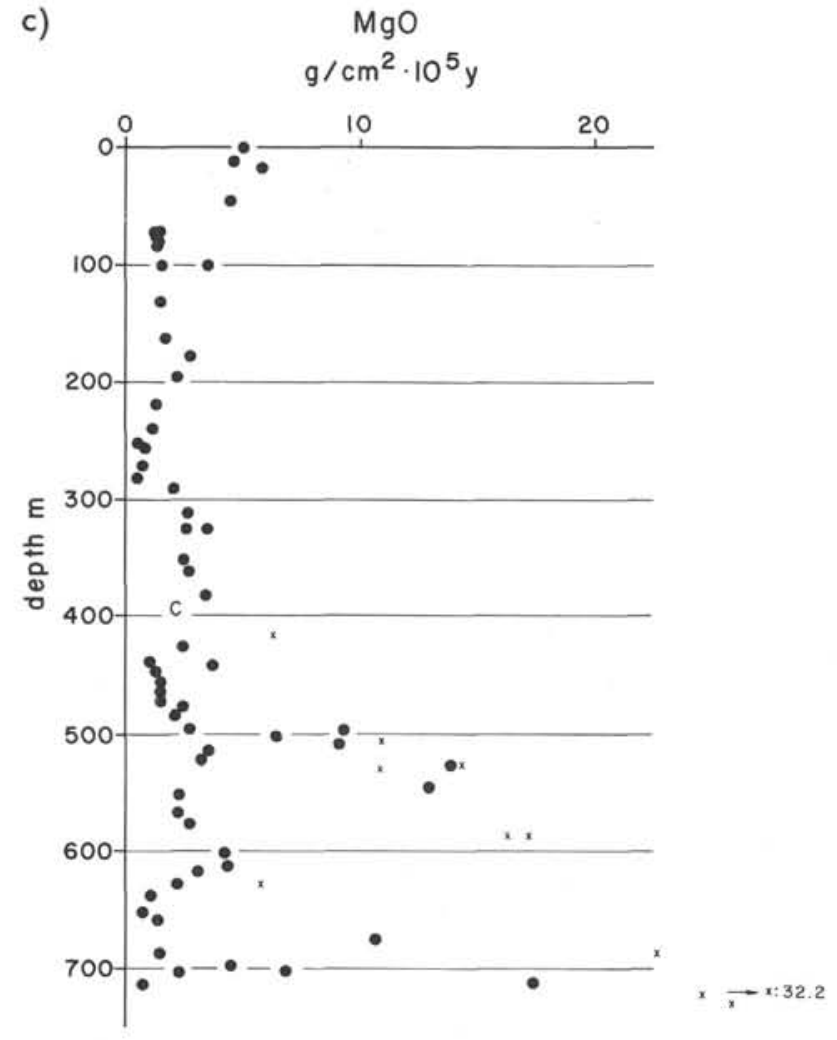

b)

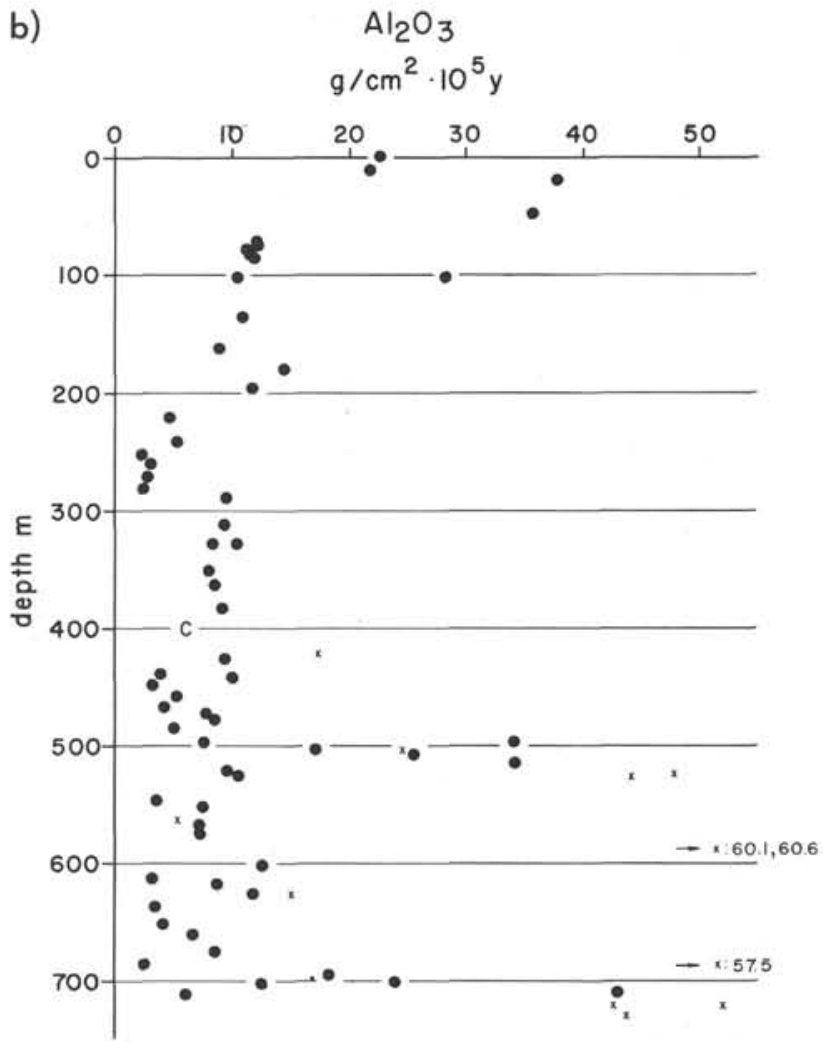

d) $\begin{gathered}\mathrm{TiO}_{2} \\ \mathrm{~g} / \mathrm{cm}^{2} \cdot 10^{5} \mathrm{y}\end{gathered}$

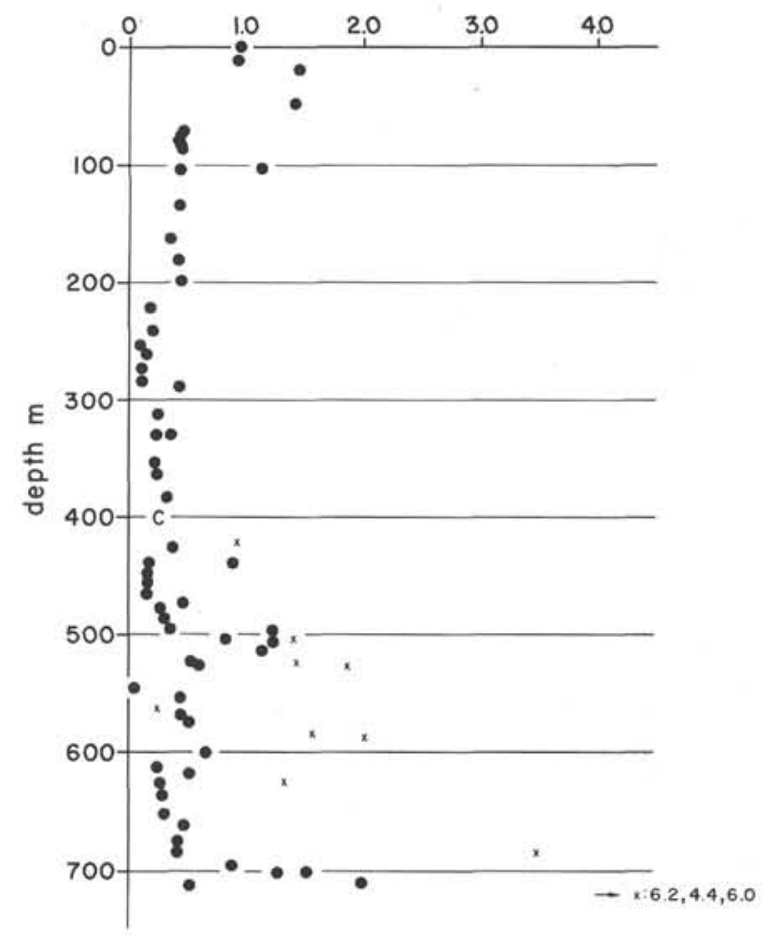

Figure 9. Plots of depth vs. rate of supply of chemical species to the sea floor. a) $\mathrm{Fe}_{2} \mathrm{O}_{3}$, b) $\mathrm{Al}_{2} \mathrm{O}_{3}$, c) $\mathrm{MgO}$, d) $\mathrm{TiO}_{2}$. Explanation as in Figure 8.

943 
a)

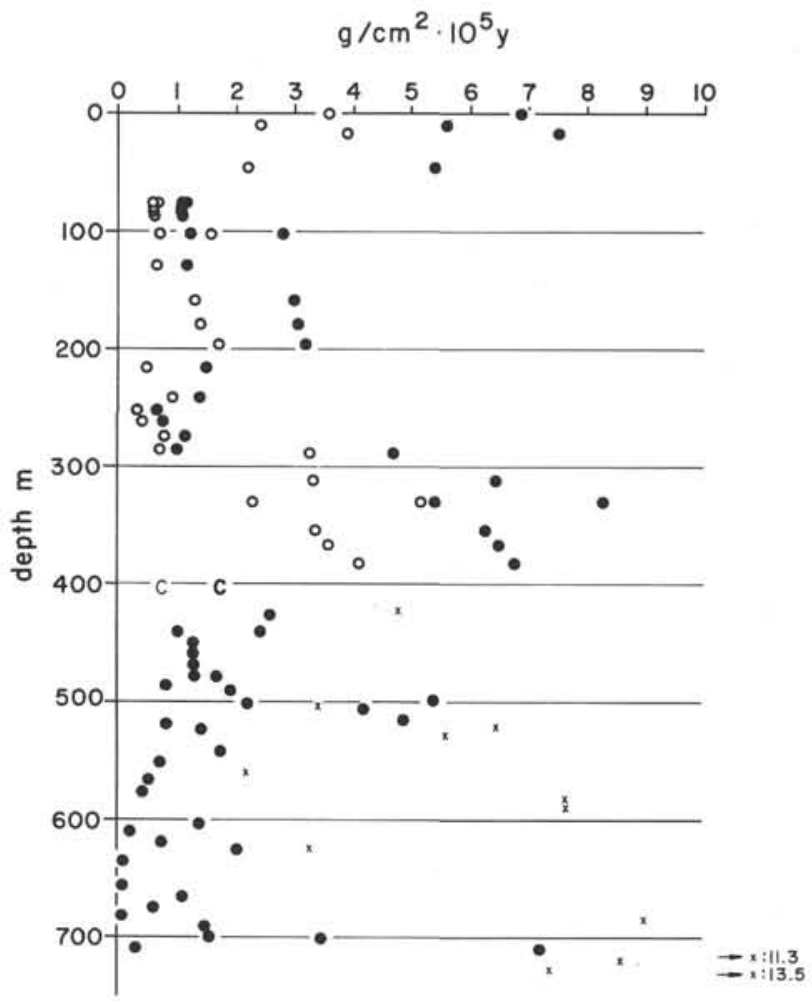

c)

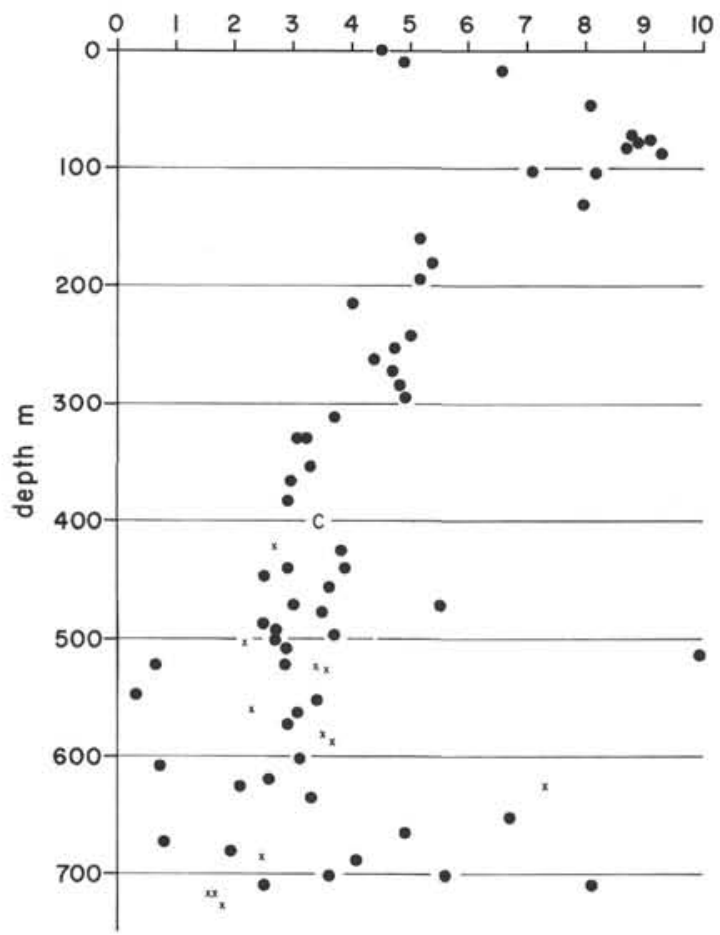

b)

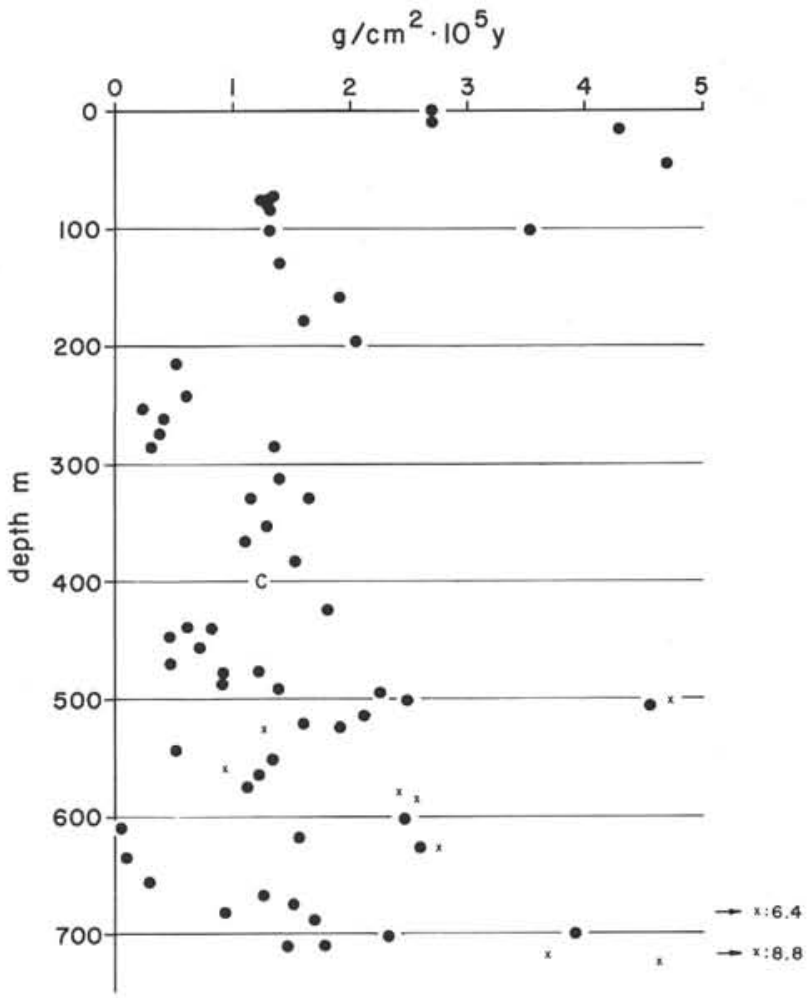

d)

$\mathrm{K} 2 \mathrm{O} / \mathrm{Na}_{2} \mathrm{O}+\mathrm{K}_{2} \mathrm{O}$

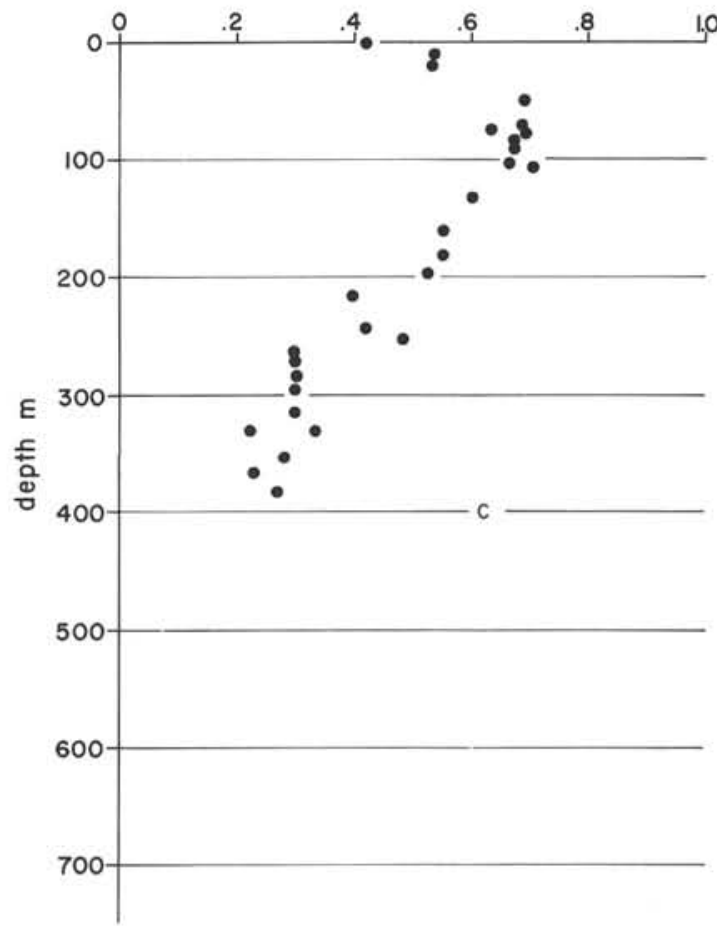

Figure 10. Plots of depth vs. rate of supply of chemical species to the sea floor and of ratios of chemical species. a) $\mathrm{Na}_{2} \mathrm{O}$, b) $\mathrm{K}_{2} \mathrm{O}$, c) $\mathrm{Al}_{2} \mathrm{O}_{3} / \mathrm{MgO}$, d) $\mathrm{K}_{2} \mathrm{O} / \mathrm{K}_{2} \mathrm{O}+\mathrm{Na}_{2} \mathrm{O}$ (fig. 10a). Explanation as in Figure 8. Open circles for Na $\mathrm{O}_{2} \mathrm{O}$ (Figure 10a) are for solid-phase sodium only, shallower than 400 meters. 
aluminum is relatively enriched over magnesium, compared to volcanic suites. Although the ratio of the two elements shows considerable scatter in the lower sequence (perhaps because of diagenetic changes forming locally highaluminum or high-magnesium authigenic mineral assemblages), the average trend is almost constant up to about 300 meters. There is a break at 300 meters, and the trend then shows a rise, peaking at about 90 meters and then dropping to the surface. This trend closely parallels the decrease in abundance of plagioclase phenocrysts seen in these sediments (Donnelly and Nalli, this volume) and appears to reflect the volcanic minimum inferred for this interval. The decrease in the $\mathrm{Al}_{2} \mathrm{O}_{3} / \mathrm{MgO}$ ratio above this level reflects the renewal of volcanic activity in the latest Tertiary.

The supply rate of sodium $\left(\mathrm{Na}_{2} \mathrm{O}\right.$, Figure $\left.10 \mathrm{a}\right)$ is more complicated to determine because of the presence in the pore water of a significant quantity of this element as a solute ion. Because the samples are dried but not previously washed, this aqueous sodium is included in the total analysis. A correction for sodium was made in the upper 400 meters based on the measured porosity in this interval and on the estimated sodium content of the water, which was presumed to be identical to that of nearby Site 29. The well-known near constancy of sodium ion contents in pore waters makes this a safe assumption. Below 400 meters no correction was made; the porosity drops abruptly at this level (suggesting a smaller correction), but the sodium ion content of the lower sequence pore waters is unknown. In Figure 10a the solid circles represent total sodium and the open circles (above $400 \mathrm{~m}$ ) sodium in solid phases. The abrupt drop in sodium below the chert level $(400 \mathrm{~m})$ matches a drop in porosity from about 60 to 70 percent to 40 percent. If we assume that the sodium content of the lower sequence pore water is about the same as that of the upper sequence, then the onset of lithification must mark a downward sharp decrease in the rate of accumulation of this element. Similar drops are not seen for aluminum (Figure 9b) magnesium (Figure 9c), or potassium (figure $10 \mathrm{~b})$. We conclude that a diagenetic effect is operative here; at the level of lithification sodium is being removed from some solid phase (probably montmorillonite) and carried upward in the pore water. The constancy of sodium ion contents in the upper pore waters, however, suggests that this process was penecontemporaneous with deposition and is not operative today. That is, at present the onset of lithification is not a front that is moving inexorably upward through the sedimentary column.

Potassium $\left(\mathrm{K}_{2} \mathrm{O}\right.$, Figure $\left.10 \mathrm{~b}\right)$ behaves much the same as aluminum, except that it is relatively enriched in the lower sequence. Like sodium, it is locally enriched in the lower sequence volcanic rocks, especially near the bottom of the core where green micas are conspicuous. The slightly high rate of supply of potassium throughout the lower sequence (relative to sodium, aluminum, and magnesium) would appear to imply a diagenetic reaction, which was nearly contemporaneous with deposition and through which potassium was preferentially supplied to a mineral phase from sea water. The identity of the mineral phase is uncertain, but both K-feldspar (some of which is certainly authigenic, see above) and clinoptilolite are found through- out the lower sequence. Mica (at least partly authigenic) is more local.

The ratio of potassium to total alkali (expressed as $\mathrm{K}_{2} \mathrm{O} / \mathrm{K}_{2} \mathrm{O}+\mathrm{Na}_{2} \mathrm{O}$, Figure 10d) was calculated for the upper 400 meters of the core (using the sodium values for solid phases only) in an attempt to separate terrigenous from volcanic sources of detrital silicate material. The relative enrichment of sodium in oceanic and circum-oceanic volcanic materials and of potassium in terrigenous clay assemblages is reflected in a sharp increase in potassium upwards, culminating in the late Tertiary clay horizon. This trend is strikingly parallel to the $\mathrm{Al}_{2} \mathrm{O}_{3} / \mathrm{mgO}$ trend (Figure 10c) and to the inferred Miocene diminution of Lesser Antillean volcanic activity referred to above.

In general we note that the lithologic break at 300 meters is paralleled by important breaks in the rates of supply of chemical species to the sea floor. In the older sequence we find high rates of silica and phosphorus, and, to a lesser extent, potassium. Above 300 meters each of these components decreases sharply. The silica drop probably reflects a sharp drop in the volume of radiolarian opal falling on the sea floor, the phosphorus a sharp rise in the solution of organic debris on the sea floor, and the potassium a cessation in the incorporation of pre-water potassium in authigenic minerals. Above 300 meters there is a brief interval with relatively low accumulation rate of total sediment followed by a striking increase in the rate of supply of all noncalcareous constituents through the end of the Tertiary. Evidently the break at 300 meters indicates the cessation of bottom currents flowing from the Pacific into the Caribbean area (through closing the barrier of the Central American isthmus), and the rise in noncalcareous constituents since that time indicates the gradual increase in terrigenous and volcanic detritus. The bulk of this debris is probably terrigenous, and the increase with time must indicate either more proximate land areas (i.e., a closing of the Caribbean basin) or a gradual uplift of surrounding land areas such that more terrigenous debris was supplied from the land to the adjoining seas. Interestingly, the rate of supply of noncalcareous constituents does not show a minimum at the clay interval of Miocene age, if our estimated rates of sedimentation are at all reasonable. This clay interval, then, would represent simply a cessation of calcium carbonate deposition (a shift in the lysocline) and not a more general subsidence of surrounding land areas. Yet the chemical character of the clay $\left(\mathrm{Al}_{2} \mathrm{O}_{3} / \mathrm{MgO}\right.$ ratio, $\mathrm{K}_{2} \mathrm{O} / \mathrm{K}_{2} \mathrm{O}+\mathrm{Na}_{2} \mathrm{O}$ radio; Figures (10c, d) does change through this interval; the noncalcareous components become most potassium- and aluminum-rich, relative to sodium and magnesium. We interpret these trends as indicating changes in the character of detritus (terrigenous clay vs. volcanic materials) rather than secondary (i.e., diagenetic) effects.

\section{ACKNOWLEDGMENTS}

We are most grateful to Max Budd and R. Morton for much of the silicate analysis. Jan O'Brien assisted in several ways, and my wife, Ailsa Donnelly, typed and otherwise helped prepare the manuscript. 


\section{PROCEDURE FOR CHEMICAL ANALYSIS}

The sediments analyzed for this report were analyzed by wet, so-called rapid methods, using the methods of Shapiro and Brannock (1962) and Shapiro (1967), as modified in our laboratory.

Samples were fused in a mixture of lithium metaborate and lithum tetraborate and the resulting beads dissolved in weak sulfuric acid solutions. Silica was determined colorimetrically, using the molybdenum blue method. Aluminum was determined using the calcium alizarin red method. Titanium was determined colorimetrically with tiron as an indicator. Phosphorus was determined colorimetrically using the molybdenum blue method with stannous chloride reduction. Manganese, calcium, sodium, potassium, magnesium, and iron were determined by absorption flame photometry. Lanthanum had been added to all samples.

For the determination of copper, strontium, and barium, 0.5 gram samples were dissolved in $\mathrm{HF}$ with $\mathrm{HNO}_{3}$ and the elements determined by absorption flame photometry, using the method of additions.

All samples had been dried for several days at $120^{\circ} \mathrm{C}$ but not washed.

\section{REFERENCES}

Bloxam, T. W., 1959. Glaucophane-schists and associated rocks near Valley Ford, California. Am. J. Sci. 257, 95.

James, H. L., 1966. Data of Geochemistry. Chapter W. Chemistry of the Iron-rich Sedimentary Rocks. U. S. Geol. Surv. Prof. Paper 440-W, 1.

Pimm, A. C., Garrison, R. E. and Boyce, R.E., 1971. Sedimentology synthesis: lithology, chemistry, and physical properties of sediments in the northwestern Pacific Ocean. In Fischer, A. G., Heezen, B. C. et al., 1971. Initial Reports of the Deep Sea Drilling Project, Volume VI. Washington (U.S. Government Printing Office). 1131.

Rex, R. W., Eklund, W. A. and Jamieson, I. M., 1971. X-Ray mineralogy studies, Leg VI. In Fischer, A. G., Heezen, B. C. et al., 1971. Initial Reports of the Deep Sea Drilling Project, Volume VI. Washington (U. S. Government Printing Office) 753.

Shapiro, L. and Brannock, W. W., 1962. Rapid analysis of silicate, carbonate, and phosphate rocks. U.S. Geol. Surv. Bull. 1144-A.

Shapiro, L., 1967. Rapid analysis of rocks and minerals by a single solution method. U. S. Geol. Surv. Prof. Paper 575-B. B187.

Williams, H. and McBirney, A. R., 1969. Volcanic history of Honduras. Univ. Calif. Publ. Geol. Sci. 85, 1 . 


\section{PLATE 1}

Authigenic Minerals

Figure 1 Barite fan, from pelagic clay. 150-3 (CC). 133X Miocene.

Figure 2 Barite fan, from pelagic clay. 150-3 (CC). 133X. Miocene.

Figure 3 Dolomite (after otolith?). 150-3 (CC). 888X. Miocene.

Figure 3 Pyrite octahedra, replacing radiolarian. 153-2 (CC). 2072X. Miocene.

Figure 4 Copper octahedra, in pelagic clay. 149-10 (CC). 2220X. Pliocene. 
PLATE 1
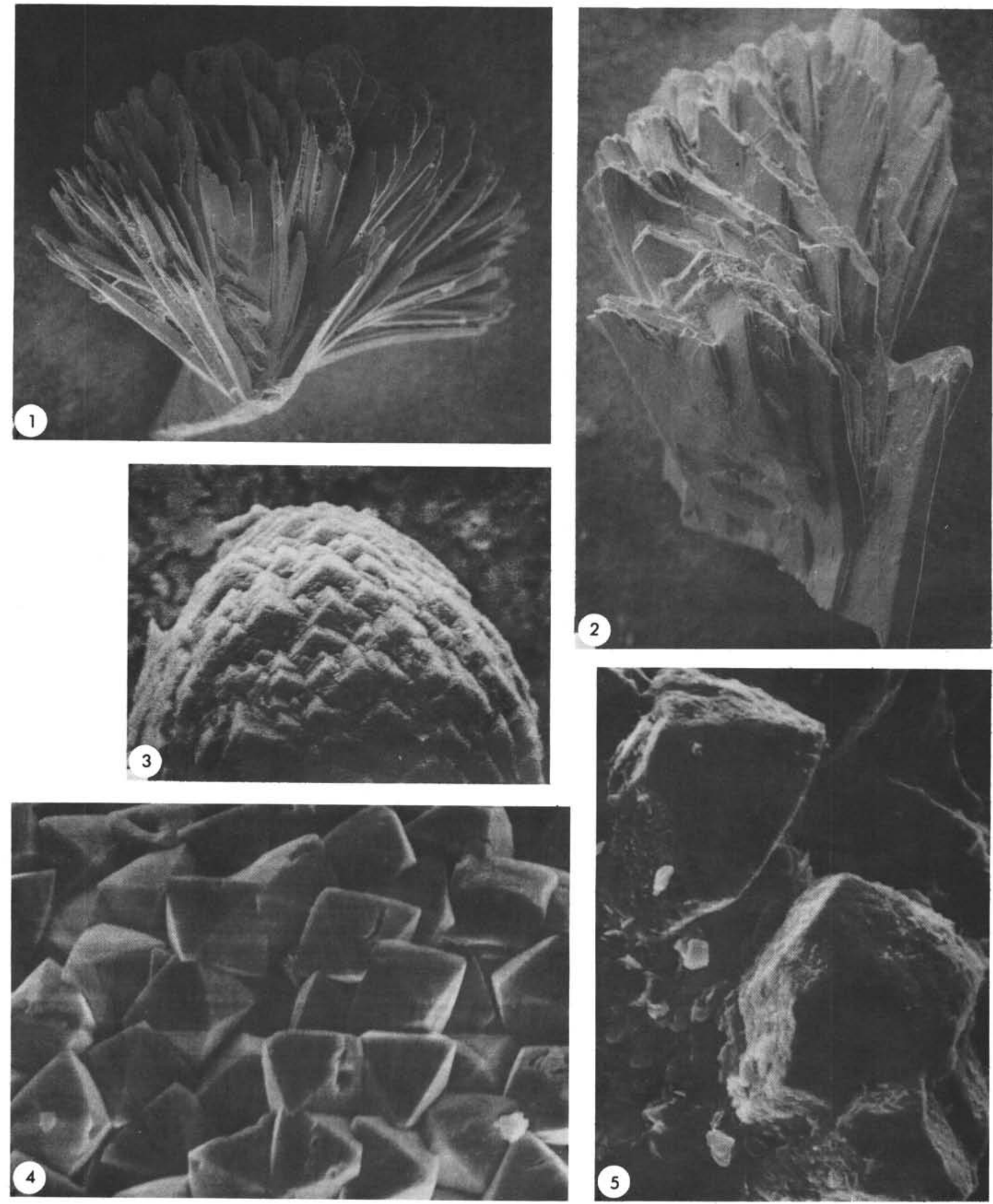


\section{PLATE 2}

Thin Sections of Fish Debris

Figure $1 \mathrm{~J}$-shaped fish bone, in burrowed, organic limestone, crossed nicols. 153-16-1(12-17). Bar is $0.5 \mathrm{~mm}$ long. Santonian.

Figure 2 Fish bones in foraminiferal limestone. $146-35-2(137-139)$. Bar is $0.5 \mathrm{~mm}$. long. Santonian.

Figure 3 Fish bone in organic limestone. 153-16-2(13-17). Santonian.

Figure 4

Fish bone in organic limestone, crossed nicols. 146-27 (CC). Bar is 100 microns long. Campanian.

Figure 5 Fish bone in organic limestone. 153-16-1(12-17). Bar is $0.5 \mathrm{~mm}$ long. Santonian.

Figure 6 Fish bone in organic limestone. 153-16-1(12-17). Bar is 100 microns long. Santonian.

Figure 7 Fish bone in organic limestone. 146-35-2(137-139). Bar is 100 microns long. Santonian. 
PLATE 2
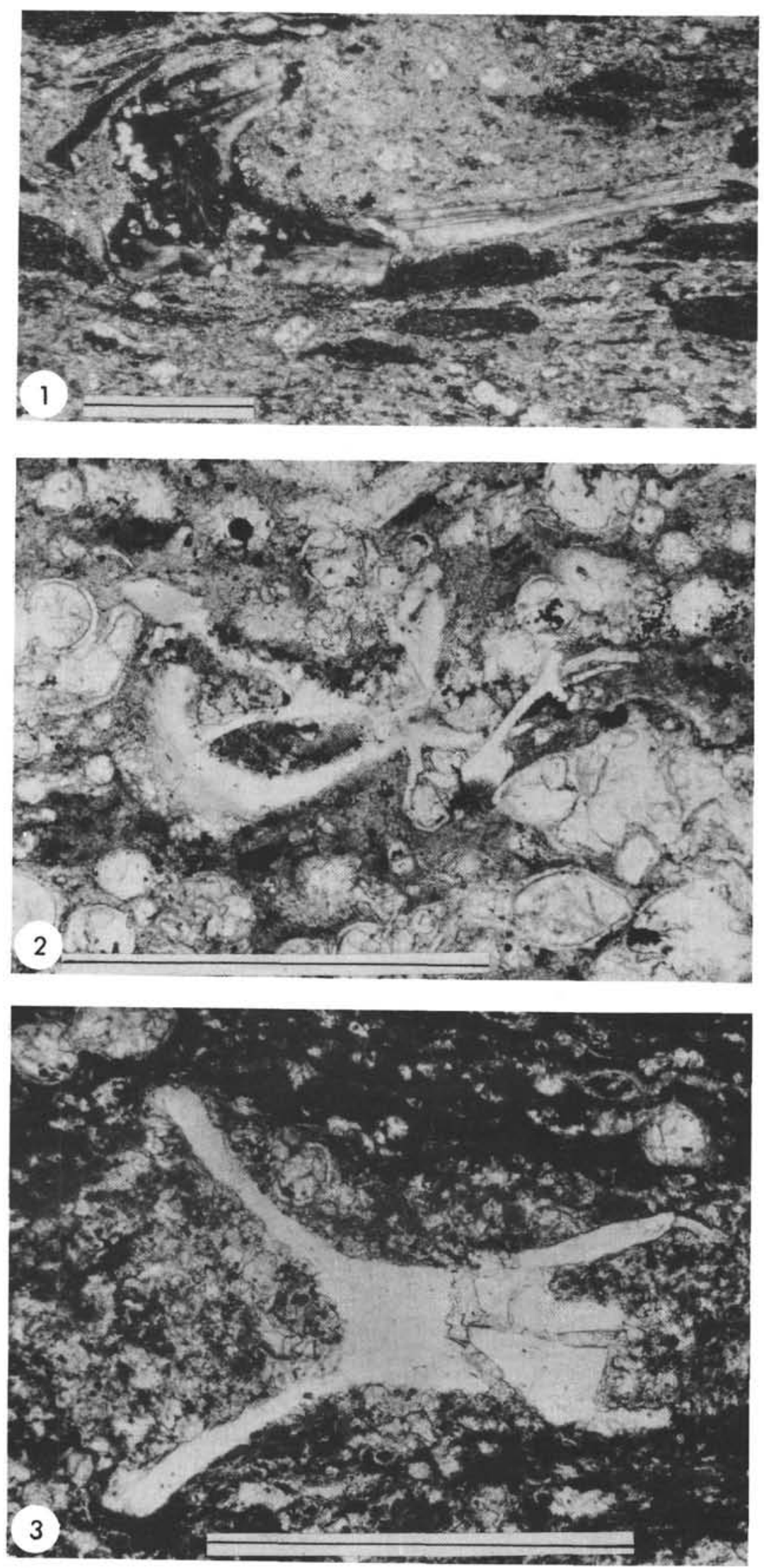
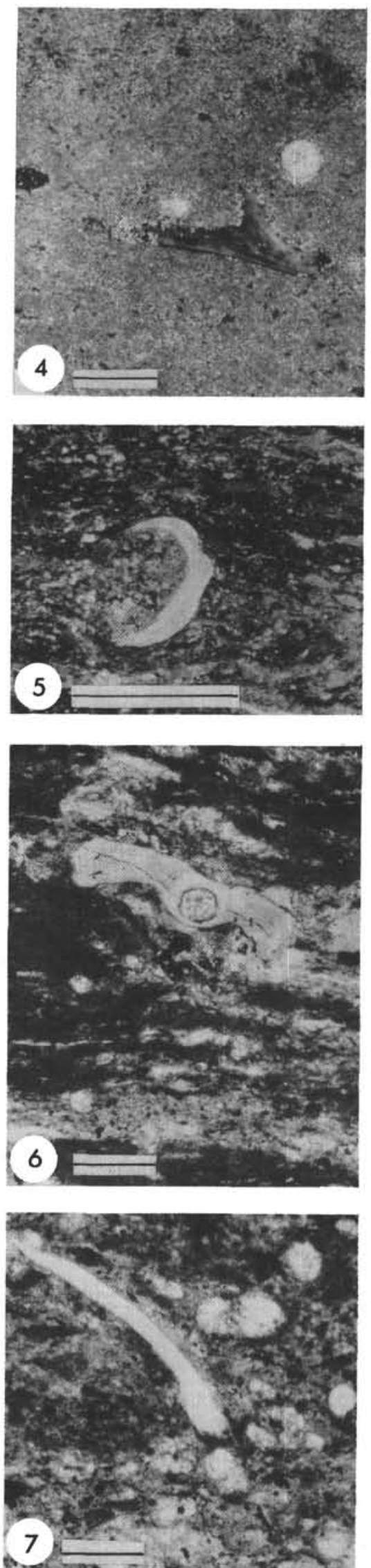
Smear slides - bar is 100 microns in each case.

Figure $1 \quad 147-18-4(70)$. Pleistocene.

Figure 2 146-41R-1(78). Coniacian.

Figure 3 146-41R-1(78). Coniacian.

Figure $4 \quad$ 146-16-1(128). Maestrichtian.

Figure 5 Fish tooth in cristobalite "clay". 146-7-1(140).

Paleocene. 


\section{PLATE 3}
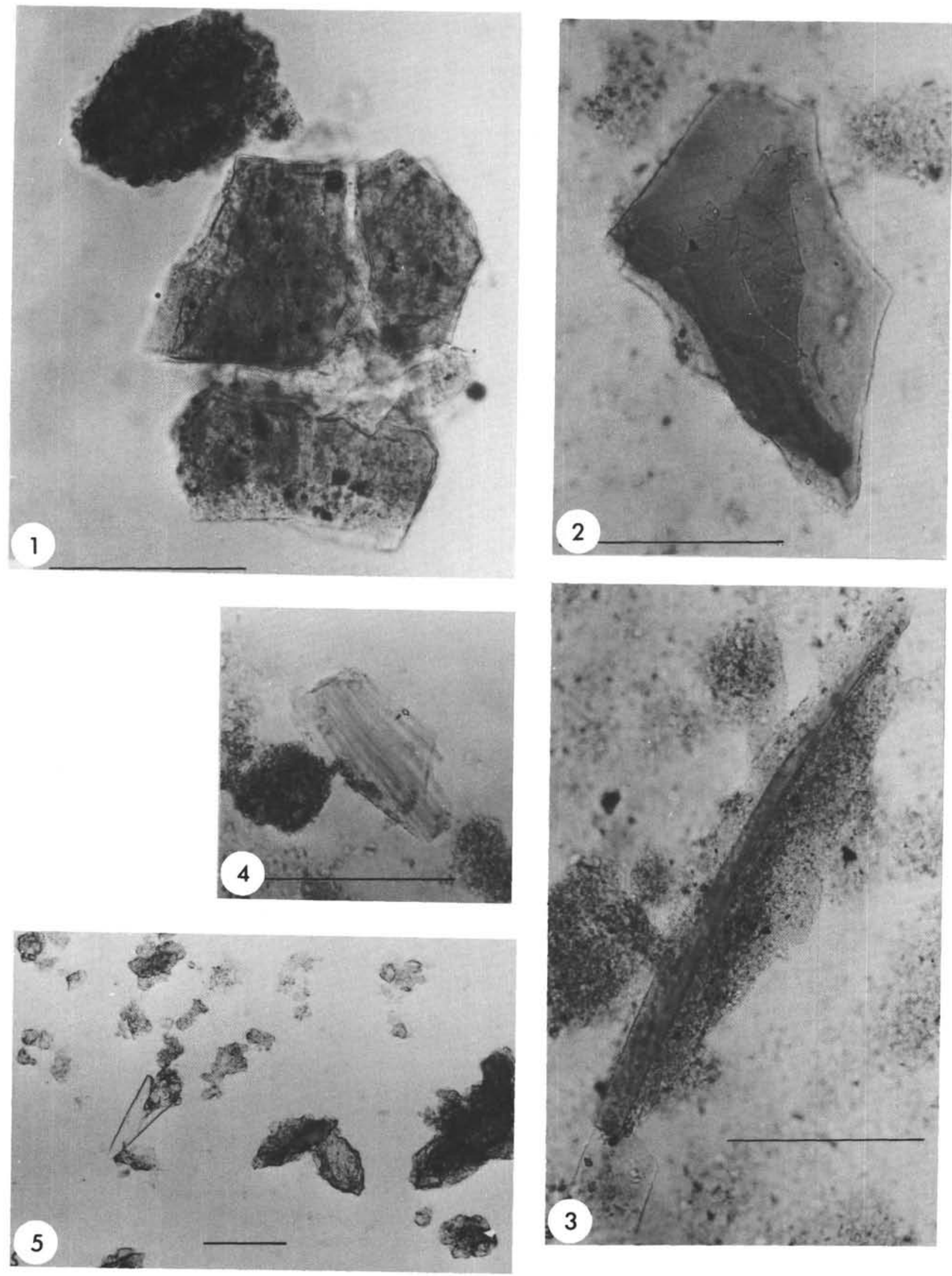
PLATE 4

Barite in Thin Section

Figure 1 Barite crystals in burrow. 146-34-1(51-56). Bar is 1 mm long. Santonian.

Figure 2 Barite euhedra in foraminiferal limestone. $153-15-4(10-14)$. Bar is 100 microns long. Maestrichtian.

Figure 3 Barite crystals in radiolarian chert. 146-3(CC). Bar is 100 microns long. Early Eocene.

Figure 4 Barite euhedron in limestone. 146-36(CC). Bar is 100 microns. Santonian. 


\section{PLATE 4}
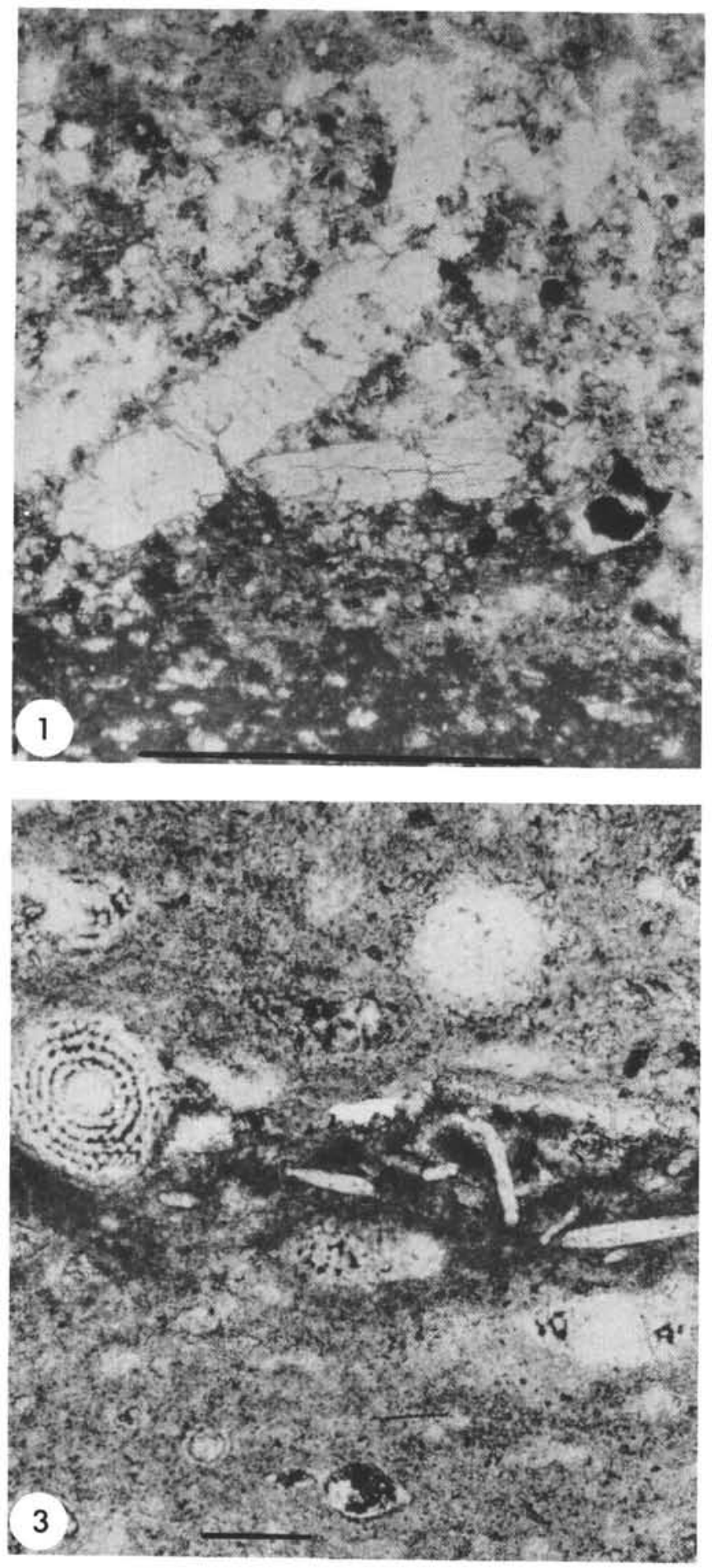
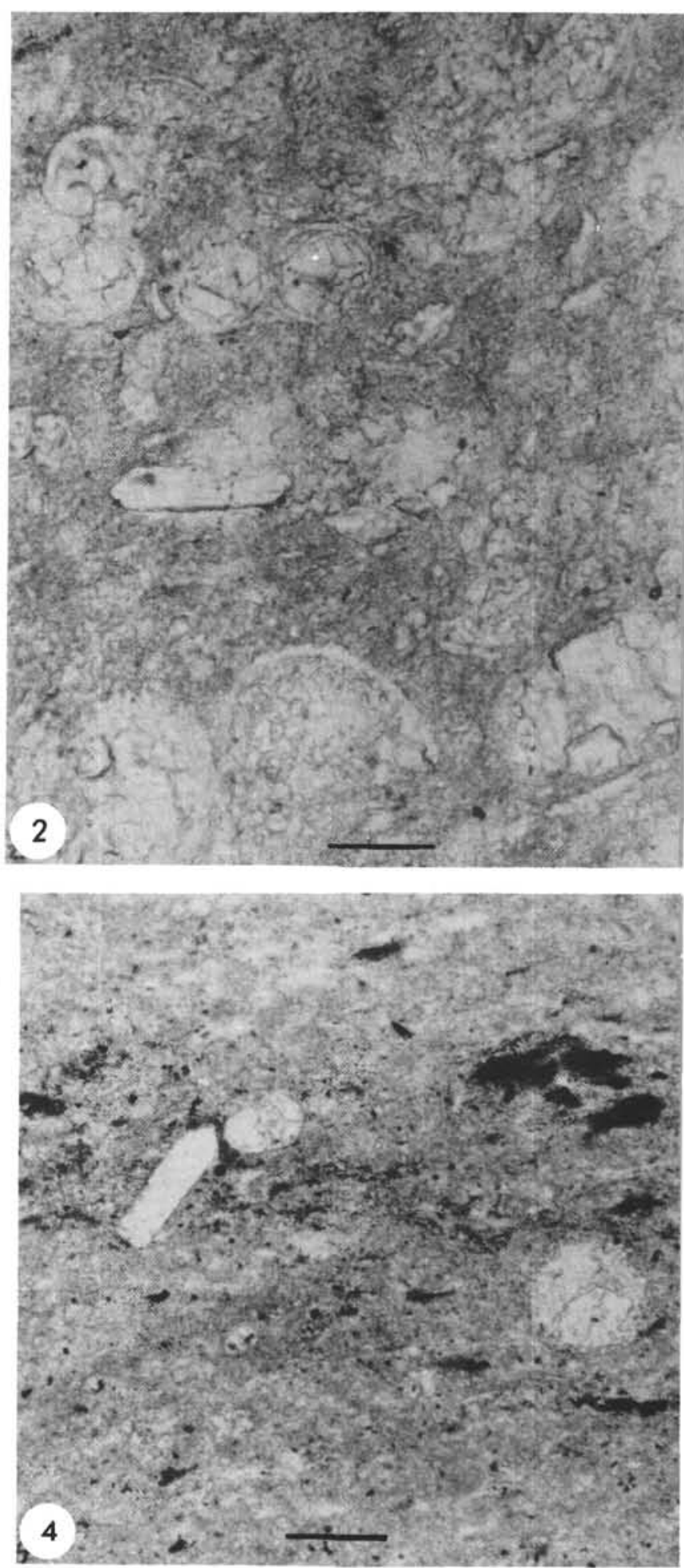
PLATE 5

Phillipsite and Clinoptilolite
Figures 1-3 Twinned phillipsite prisms and aggregates, with biotite flakes and foraminiferal debris. 153-1-6(133-134).

Figure 4 Phillipsite prims, showing characteristic termination. 150-4-1(114/115). Miocene.

Figure 5 Clinoptilolite prism, showing characteristically blunter termination angle. 150-5(CC). Miocene.

Figure 6 Phillipsite prism and tiny clinoptilolite crystals. 150-5(CC). Miocene. 


\section{PLATE 5}
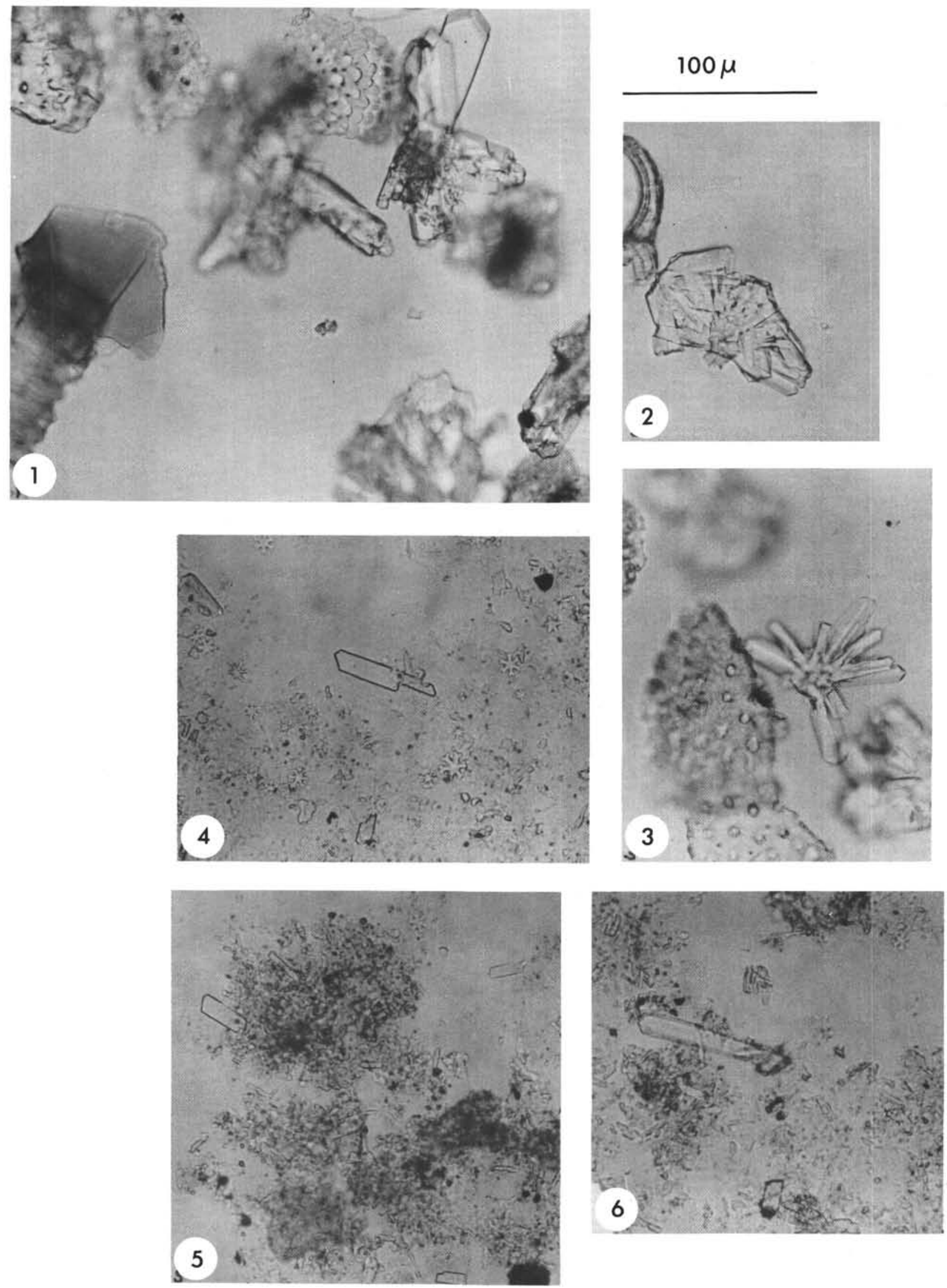


\section{PLATE 6}

Clinoptilolite

Figure 1 Clinoptilolite crystals, 150-9(CC). Santonian.

Figure 2 Clinoptilolite crystals, 152-17-2(71). Maestrichtian.

Figure 3 Ragged clinoptilolite crystals, 151-11-5(32). Early Paleocene.

Figures 4 and 7 Clinoptilolite crystals, flattened on [?101] 152-10(CC). Paleocene.

Figure 5 Clinoptilolite crystal, 150-9-1(118). Santonian.

Figure 6 Clinoptilolite crystal, 152-10(CC). Paleocene.

Figure 8 Clinoptilolite ?twin, 152-10(CC). Paleocene.

Figure 9 Ragged clinoptilolite "shreds". 146-5-1(5). Eocene. 
PLATE 6
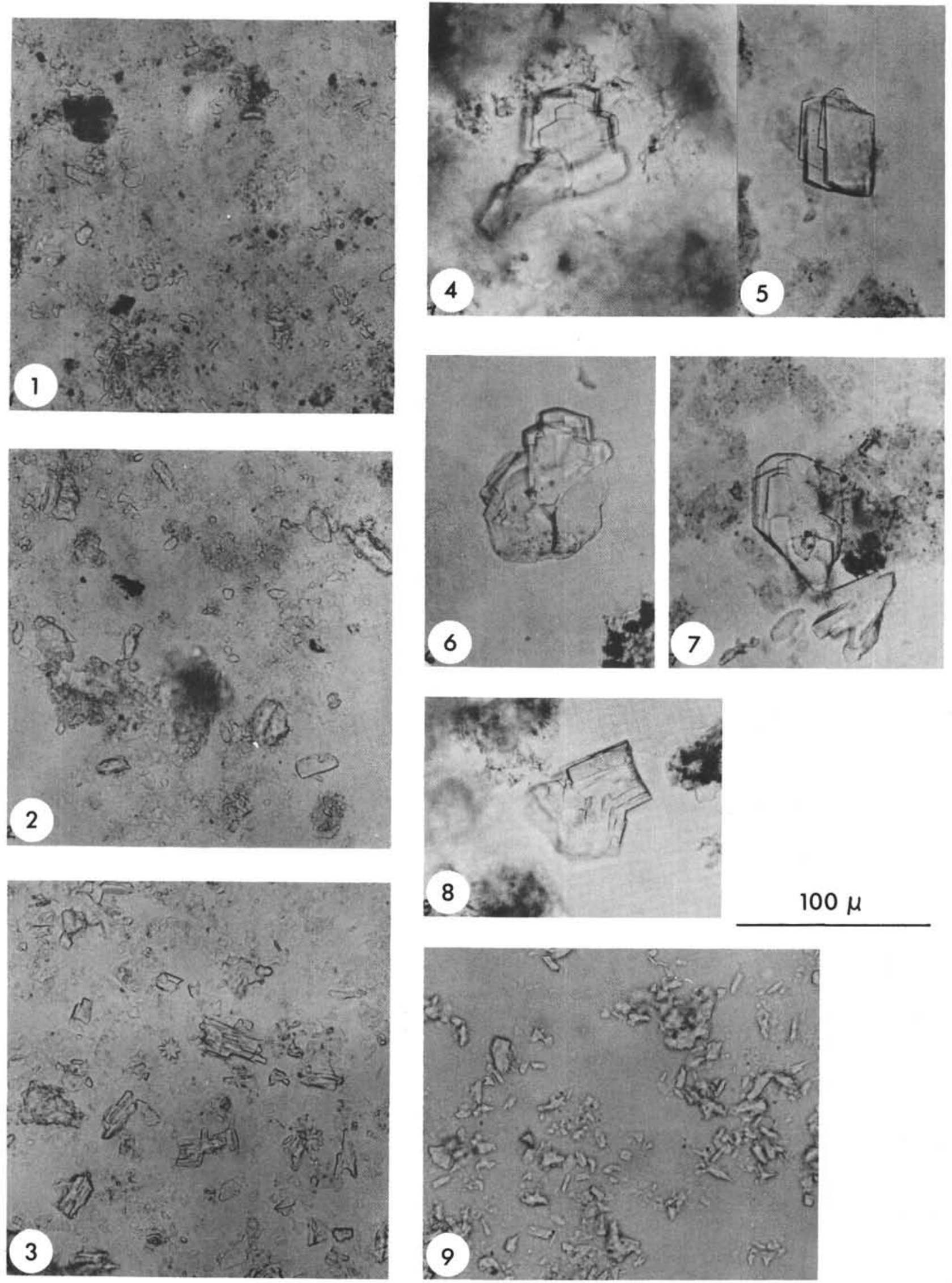
Authigenic Minerals

Figure 1 Authigenic K-feldspar, flattened on [010] with prominent [001], [101], and small [201] faces, and inclusion trains parallel to c-axis, 154-13-1(80). Bar is 100 microns long. Miocene.

Figure 2 Authigenic K-feldspar. 153-18-2(10-15). Bar is 100 microns long. Coniacian.

Figure 3 Large authigenic K-feldspar, crowded with inclusions. $150-10-2(100)$. Bar is 300 microns long. Santonian.

Figure 4 Authigenic K-feldspar. 150-10-2(100). Bar is 100 microns long. Santonian.

Figure 5 Authigenic K-feldspar. 153-18-2(10-15). Bar is 100 microns long. Coniacian.

Figure 6 Authigenic K-feldspar. 150-10-2(100). Bar is 100 microns long. Santonian.

Figure 7 Bariet euhedron, flattened on [001], showing [210] faces. 146-26-1(133). Bar is 100 microns long. Campanian.

Figures 8,9 Garnet, fragments of ?skeletal crystal, showing growth lines. 146-15-4(10). Bars are 50 microns long. Maestrichtian.

Figure 10 Anatase dipyramid in pelagic clay. 153-4-1(79). Bar is 10 microns long. Miocene.

Figures 11-13 ?Sphalerite crystals (tetrahedra with modifying negative tetrahedra) in pelagic clay. 153-4-3(103). Bars are 10 microns long. Miocene. 


\section{PLATE 7}
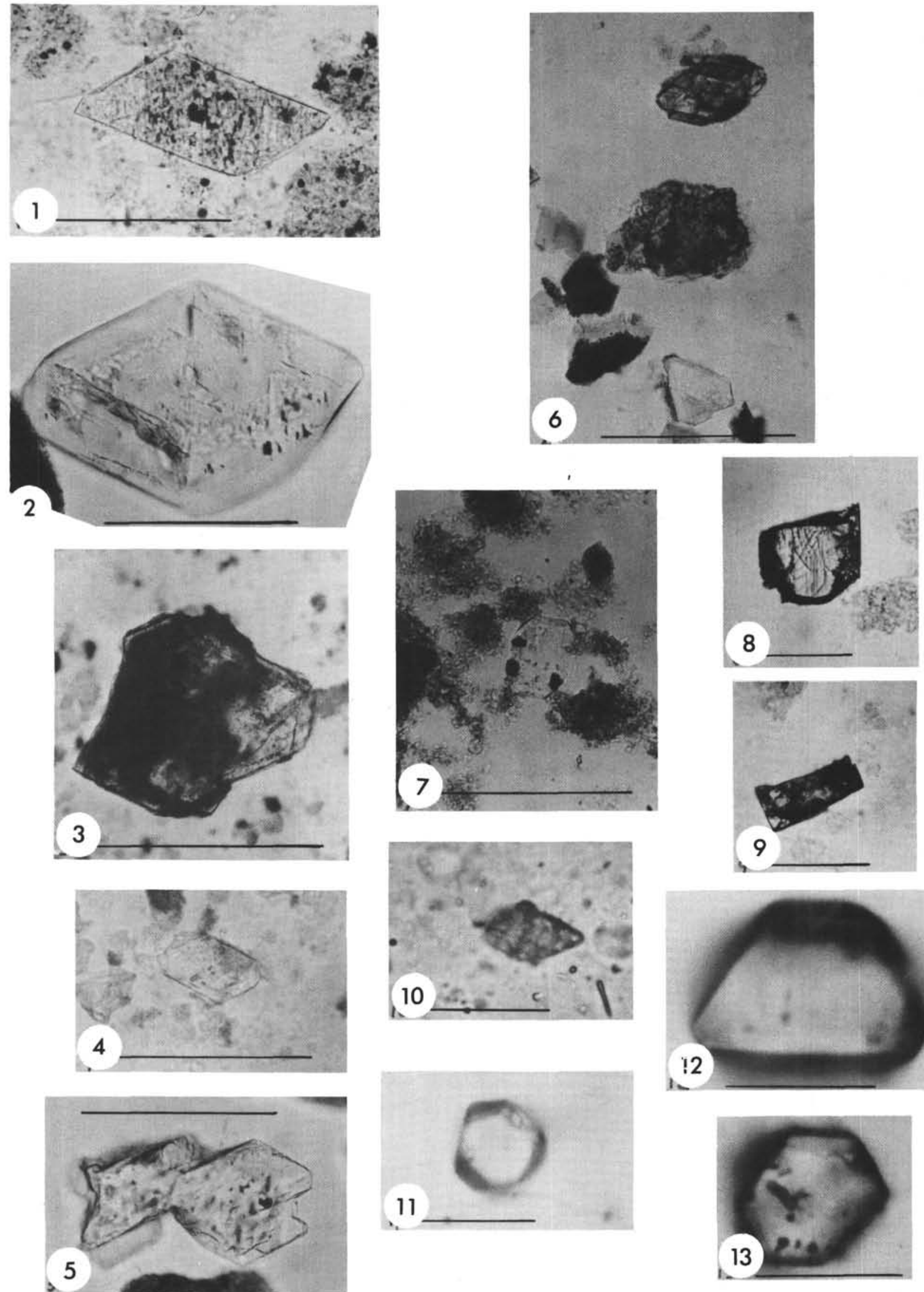